\title{
Short- and medium-term atmospheric constituent effects of very large solar proton events
}

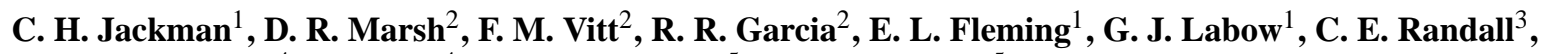 \\ M. López-Puertas ${ }^{4}$, B. Funke ${ }^{4}$, T. von Clarmann ${ }^{5}$, and G. P. Stiller ${ }^{5}$ \\ ${ }^{1}$ NASA/Goddard Space Flight Center, Greenbelt, MD, USA \\ ${ }^{2}$ National Center for Atmospheric Research, Boulder, CO, USA \\ ${ }^{3}$ University of Colorado, Boulder, CO, USA \\ ${ }^{4}$ Instituto de Astrofisica de Andalucia, CSIC, Granada, Spain \\ ${ }^{5}$ Institut für Meteorologie und Klimaforschung, Forschungszentrum Karlsruhe and Univ. Karlsruhe, Karlsruhe, Germany
}

Received: 26 June 2007 - Published in Atmos. Chem. Phys. Discuss.: 23 July 2007

Revised: 28 November 2007 - Accepted: 15 January 2008 - Published: 14 February 2008

\begin{abstract}
Solar eruptions sometimes produce protons, which impact the Earth's atmosphere. These solar proton events (SPEs) generally last a few days and produce high energy particles that precipitate into the Earth's atmosphere. The protons cause ionization and dissociation processes that ultimately lead to an enhancement of odd-hydrogen and oddnitrogen in the polar cap regions $\left(>60^{\circ}\right.$ geomagnetic latitude). We have used the Whole Atmosphere Community Climate Model (WACCM3) to study the atmospheric impact of SPEs over the period 1963-2005. The very largest SPEs were found to be the most important and caused atmospheric effects that lasted several months after the events. We present the short- and medium-term (days to a few months) atmospheric influence of the four largest SPEs in the past 45 years (August 1972; October 1989; July 2000; and October-November 2003) as computed by WACCM3 and observed by satellite instruments. Polar mesospheric $\mathrm{NO}_{\mathrm{x}}\left(\mathrm{NO}+\mathrm{NO}_{2}\right)$ increased by over $50 \mathrm{ppbv}$ and mesospheric ozone decreased by over $30 \%$ during these very large SPEs. Changes in $\mathrm{HNO}_{3}, \mathrm{~N}_{2} \mathrm{O}_{5}, \mathrm{ClONO}_{2}, \mathrm{HOCl}$, and $\mathrm{ClO}$ were indirectly caused by the very large SPEs in October-November 2003, were simulated by WACCM3, and previously measured by Envisat Michelson Interferometer for Passive Atmospheric Sounding (MIPAS). WACCM3 output was also represented by sampling with the MIPAS averaging kernel for a more valid comparison. Although qualitatively similar, there are discrepancies between the model and measurement with WACCM3 predicted $\mathrm{HNO}_{3}$ and $\mathrm{ClONO}_{2}$ enhancements being smaller than measured and $\mathrm{N}_{2} \mathrm{O}_{5}$ enhancements being larger than measured. The $\mathrm{HOCl}$ enhancements were fairly

Correspondence to: C. H. Jackman

(charles.h.jackman@nasa.gov)
\end{abstract}

similar in amounts and temporal variation in WACCM3 and MIPAS. WACCM3 simulated $\mathrm{ClO}$ decreases below $50 \mathrm{~km}$, whereas MIPAS mainly observed increases, a very perplexing difference. Upper stratospheric and lower mesospheric $\mathrm{NO}_{\mathrm{x}}$ increased by over $10 \mathrm{ppbv}$ and was transported during polar night down to the middle stratosphere in several weeks past the SPE. The WACCM3 simulations confirmed the SH HALOE observations of enhanced $\mathrm{NO}_{\mathrm{x}}$ in September 2000 as a result of the July 2000 SPE and the NH SAGE II observations of enhanced $\mathrm{NO}_{2}$ in March 1990 as a result of the October 1989 SPEs.

\section{Introduction}

The Earth's atmosphere is occasionally bombarded by a large flux of protons during solar proton events (SPEs). Although relatively infrequent, some of the especially large SPEs have been documented to have a substantial influence on chemical constituents in the polar middle atmosphere, especially $\mathrm{HO}_{\mathrm{x}}$, $\mathrm{NO}_{\mathrm{y}}$, and ozone (e.g. Weeks et al., 1972; Heath et al., 1977; Reagan et al., 1981; McPeters et al., 1981; Thomas et al., 1983; McPeters and Jackman, 1985; McPeters, 1986; Jackman and McPeters, 1987; Zadorozhny et al., 1992; Jackman et al., 1995, 2001, 2005a; Randall et al., 2001; Seppala et al., 2004, 2006; López-Puertas et al., 2005a, b; von Clarmann et al., 2005; Orsolini et al., 2005; Degenstein et al., 2005; Rohen et al., 2005; Verronen et al., 2006). The influx of solar protons during large events, which are more frequent near solar maximum, can strongly perturb the chemical composition of the polar middle atmosphere via ionization, dissociation, dissociative ionization, and excitation processes.

Published by Copernicus Publications on behalf of the European Geosciences Union. 
The important constituent families of $\mathrm{HO}_{\mathrm{x}}(\mathrm{H}, \mathrm{OH}$, $\left.\mathrm{HO}_{2}\right)$ and $\mathrm{NO}_{\mathrm{y}}\left(\mathrm{N}\left({ }^{4} \mathrm{~S}\right), \mathrm{N}\left({ }^{2} \mathrm{D}\right), \mathrm{NO}, \mathrm{NO}_{2}, \mathrm{NO}_{3}, \mathrm{~N}_{2} \mathrm{O}_{5}\right.$, $\mathrm{HNO}_{3}, \mathrm{HO}_{2} \mathrm{NO}_{2}, \mathrm{ClONO}_{2}, \mathrm{BrONO}_{2}$ ) are produced either directly or through a photochemical sequence as a result of SPEs. The SPE-produced $\mathrm{HO}_{\mathrm{x}}$ constituents are important in controlling ozone in the upper stratosphere and mesosphere (pressures less than about $2 \mathrm{hPa}$ ). Short-term ozone destruction via the $\mathrm{HO}_{\mathrm{x}}$ species proceeds through several catalytic loss cycles such as

$$
\begin{aligned}
& \mathrm{OH}+\mathrm{O}_{3} \rightarrow \mathrm{HO}_{2}+\mathrm{O}_{2} \\
& \text { followed by } \mathrm{HO}_{2}+\mathrm{O} \rightarrow \mathrm{OH}+\mathrm{O}_{2} \\
& \text { Net: } \mathrm{O}+\mathrm{O}_{3} \rightarrow \mathrm{O}_{2}+\mathrm{O}_{2} \\
& \text { and } \mathrm{H}+\mathrm{O}_{3} \rightarrow \mathrm{OH}+\mathrm{O}_{2} \\
& \text { followed by } \mathrm{OH}+\mathrm{O} \rightarrow \mathrm{H}+\mathrm{O}_{2}
\end{aligned}
$$$$
\text { Net: } \mathrm{O}+\mathrm{O}_{3} \rightarrow \mathrm{O}_{2}+\mathrm{O}_{2} \text {. }
$$

The SPE-produced $\mathrm{NO}_{\mathrm{x}}\left(\mathrm{NO}+\mathrm{NO}_{2}\right)$ constituents lead to short- and longer-term catalytic ozone destruction in the lower mesosphere and stratosphere (pressures greater than about $0.5 \mathrm{hPa}$ ) via the well-known $\mathrm{NO}_{\mathrm{x}}$-ozone loss cycle

$$
\begin{aligned}
& \mathrm{NO}+\mathrm{O}_{3} \rightarrow \mathrm{NO}_{2}+\mathrm{O}_{2} \\
& \text { followed by } \mathrm{NO}_{2}+\mathrm{O} \rightarrow \mathrm{NO}+\mathrm{O}_{2}
\end{aligned}
$$

Net: $\mathrm{O}+\mathrm{O}_{3} \rightarrow \mathrm{O}_{2}+\mathrm{O}_{2}$.

There have been a number of modeling studies focused on understanding and predicting the atmospheric influence of SPEs (e.g. Warneck, 1972; Swider and Keneshea, 1973; Crutzen et al., 1975; Swider et al., 1978; Banks, 1979; Fabian et al., 1979; Jackman et al., 1980, 1990, 1993, 1995, 2000, 2007; Solomon and Crutzen, 1981; Rusch et al., 1981; Solomon et al., 1981, 1983; Reagan et al., 1981; Jackman and McPeters, 1985; Roble et al., 1987; Reid et al., 1991; Vitt and Jackman, 1996; Vitt et al., 2000; Krivolutsky et al., 2001, 2003, 2005, 2006; Verronen et al., 2002, 2005, 2006; Semeniuk et al., 2005). Most of these studies were carried out with lower dimensional models (0-D, 1-D, 2-D); however, a few used three-dimensional (3-D) models (e.g. Jackman et al., 1993, 1995, 2007; Semeniuk et al., 2005; Krivolutsky et al., 2006) to investigate the more detailed global effects of SPEs.

In this study we have used version 3 of the Whole Atmosphere Community Climate Model (WACCM3), which is a fully coupled general circulation with photochemistry model with a domain that extends from the ground to the lower thermosphere. WACCM3 allows study of the detailed timedependent 3-D atmospheric response to a variety of perturbations. Earlier studies of SPEs with 3-D models focused on single very large SPE periods. For example, Jackman et al. (1993, 1995) studied the October 1989 SPEs; Semeniuk et al. (2005) and Jackman et al. (2007) investigated the October/November 2003 SPEs; and Krivolutsky et al. (2006) considered the July 2000 SPE. The purpose of this work is to use WACCM3 to investigate the global effects of four very large SPE periods over solar cycles 20-23 (years 19632005), namely, the August 1972, October 1989, July 2000, and October 2003 SPEs. The atmosphere was undergoing substantial changes from 1963-2005 with ground chlorine source gas amounts increasing from about 0.9 to $3.3 \mathrm{ppbv}$ and ground carbon dioxide amounts increasing from about 317 to 380 ppmv. Also, the SPE periods themselves were somewhat different with significant variations in the temporal and altitudinal extent and intensity of the particular events.

Some recent work (e.g., Jackman et al., 2001, 2005a; Rohen et al., 2005; Krivolutsky et al., 2006) has indicated that the observed $\mathrm{NO}_{\mathrm{x}}$ enhancements and ozone decreases during and shortly after SPEs can be fairly reasonably simulated. However, recent measurements of SPE-caused short-term enhancements of $\mathrm{HOCl}, \mathrm{ClO}$, and $\mathrm{ClONO}_{2}$ (von Clarmann et al., 2005) and $\mathrm{HNO}_{3}$ and $\mathrm{N}_{2} \mathrm{O}_{5}$ (López-Puertas et al., 2005b) have not yet been compared with global model simulations in the literature to the best of our knowledge. Also, the medium-term polar enhancements in $\mathrm{NO}_{\mathrm{x}}$ in September 2000 attributed to the July 2000 SPE (Randall et al., 2001) have not yet been modeled with a general circulation model as far as we know.

This investigation will focus on the short-and mediumterm (days to months) atmospheric influence caused by the very large SPE periods in August 1972, October 1989, July 2000, and October-November 2003. We will compare our WACCM3 predictions with observations from several satellite instruments documenting SPE effects during these four periods. As part of this analysis we will discuss SPEcaused short-term enhancements in $\mathrm{HNO}_{3}, \mathrm{~N}_{2} \mathrm{O}_{5}, \mathrm{HOCl}$, $\mathrm{ClONO}_{2}$, and $\mathrm{ClO}$ and compare WACCM3 and satellite measurements in October-November 2003. We will also compare WACCM3 with observations of the medium-term $\mathrm{NO}_{\mathrm{x}}$ enhancements caused by the SPEs (up to several months past the events). This study will ultimately provide a test of the ability of a general circulation model with chemistry to simulate several different SPE periods.

This paper is divided into seven primary sections, including the Introduction. The solar proton flux and ionization rate computation are discussed in Sect. 2 and SPE-induced production of $\mathrm{HO}_{\mathrm{x}}$ and $\mathrm{NO}_{\mathrm{y}}$ are discussed in Sect. 3. A description of the satellite instrument measurements and WACCM3 is given in Sect. 4. WACCM3 model results for short-term (days) constituent changes, with comparisons to measurements for some very large SPEs of the past 45 years, are shown in Sect. 5 while medium-term (months) constituent changes caused by SPEs are discussed in Sect. 6. The conclusions are presented in Sect. 7. 


\section{Proton measurement/ionization rates}

Solar proton fluxes have been measured by a number of satellites in interplanetary space or in orbit around the Earth. The National Aeronautics and Space Administration (NASA) Interplanetary Monitoring Platform (IMP) series of satellites provided measurements of proton fluxes from 1963-1993 (Jackman et al., 1990; Vitt and Jackman, 1996). The National Oceanic and Atmospheric Administration (NOAA) Geostationary Operational Environmental Satellites (GOES) were used for proton fluxes from 1994-2005 (Jackman et al., 2005b).

Proton flux data from IMP 1-7 were used for the years 1963-1973. These data were taken from T. Armstrong and colleagues (University of Kansas, private communication, 1986; see Armstrong et al. (1983) for a discussion of the IMP 1-7 satellite measurements). A power law was used to fit these flux data as a function of energy, which were assumed to be valid over the range 5-100 MeV (Jackman et al., 1990) and then degraded in energy using the scheme first discussed in Jackman et al. (1980). The scheme includes the deposition of energy by all the protons and associated secondary electrons. The energy required to create one ion pair was assumed to be $35 \mathrm{eV}$ (Porter et al., 1976).

IMP 8 was used for the proton flux data for the years 19741993. Vitt and Jackman (1996) take advantage of the measurements of alpha particles by IMP 8 as well and use proton fluxes from $0.38-289 \mathrm{MeV}$ and alpha fluxes from 0.82 $37.4 \mathrm{MeV}$ in energy deposition computations. The energy deposition methodology is similar to that discussed in Jackman et al. (1980). Alpha particles were found to add about $10 \%$ to the total ion pair production during SPEs.

Four GOES satellites are used for the proton fluxes in years 1994-2005: 1) GOES-7 for the period 1 January 1994 through 28 February 1995; 2) GOES-8 for the period 1 March 1995 through 8 April 2003, and 10 May 2003 to 18 June 2003; 3) GOES-11 for the period 19 June 2003 to 31 December 2005; and 4) GOES-10 to fill in the gap of missing proton flux data from 9 April through 9 May 2003. The GOES satellite proton fluxes are fit with exponential spectral forms in three energy intervals: $1-10 \mathrm{MeV}, 10-50 \mathrm{MeV}$, and $50-300 \mathrm{MeV}$. The energy deposition methodology again is that discussed in Jackman et al. (1980).

There are uncertainties associated with these proton fluxes, especially given the large number of satellite instruments used to compile the measurement record. We have made some straightforward comparisons of particular proton flux measuring instruments and estimate the proton flux uncertainties to be up to 50\%. Although it is beyond the scope of the present study to undertake a more detailed comparison, we recommend that such an investigation be accomplished by experts in the field of solar particle observations.

The daily average ion pair production rates for years 19632005 were computed from the energy deposition assuming $35 \mathrm{eV} /$ ion-pair. An example of the daily average ionization

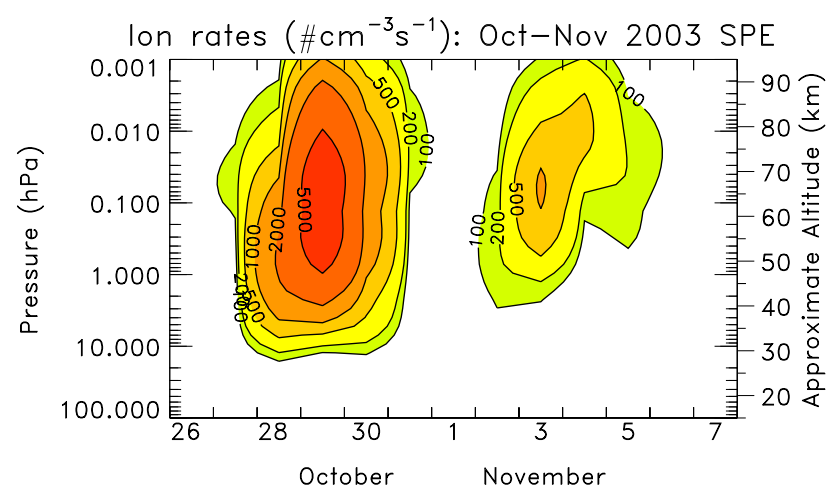

Fig. 1. Daily average ion pair production rates using the GOES 11 proton flux measurements for 26 October through 7 November 2003. Contour levels are 100, 200, 500, 1000, 2000, and $5000 \mathrm{~cm}^{-3} \mathrm{~s}^{-1}$.

rate $\left(\mathrm{cm}^{-3} \mathrm{~s}^{-1}\right)$ is given in Fig. 1 for a thirteen day period in October-November 2003, a very intense period of SPEs. The 28-31 October 2003 SPE period was the fourth largest of the past 45 years (see Table 1). Very large daily average ionization rates of $>5000 \mathrm{~cm}^{-3} \mathrm{~s}^{-1}$ extending from 0.01 to $1 \mathrm{hPa}$ are computed for 29 October 2003. Large ionization rates $>1000 \mathrm{~cm}^{-3} \mathrm{~s}^{-1}$ extending from the upper stratosphere through the mesosphere are computed for 28-30 October 2003.

These ionization rate data are provided as functions of pressure between $888 \mathrm{hPa}(\sim 1 \mathrm{~km})$ and $8 \times 10^{-5} \mathrm{hPa}$ $(\sim 115 \mathrm{~km})$ at the SOLARIS (Solar Influence for SPARC) website (http://www.geo.fu-berlin.de/en/met/ag/strat/ research/SOLARIS/Input_data/index.html) and can be used in model simulations.

\section{Odd hydrogen $\left(\mathrm{HO}_{\mathrm{x}}\right)$ and odd nitrogen $\left(\mathrm{NO}_{\mathrm{y}}\right)$ pro- duction}

\subsection{Odd hydrogen $\left(\mathrm{HO}_{\mathrm{x}}\right)$ production}

Protons and their associated secondary electrons produce odd hydrogen $\left(\mathrm{HO}_{\mathrm{x}}\right)$. The production of $\mathrm{HO}_{\mathrm{x}}$ takes place after the initial formation of ion-pairs and is the end result of complex ion chemistry (Swider and Keneshea, 1973; Frederick, 1976; Solomon et al., 1981). Generally, each ion pair results in the production of approximately two $\mathrm{HO}_{\mathrm{x}}$ species in the upper stratosphere and lower mesosphere. In the middle and upper mesosphere, an ion pair is calculated to produce less than two $\mathrm{HO}_{\mathrm{x}}$ species. The $\mathrm{HO}_{\mathrm{x}}$ production from SPEs is included in WACCM3 using a lookup table from Jackman et al. (2005a, Table 1), which is based on the work of Solomon et al. (1981). The $\mathrm{HO}_{\mathrm{x}}$ constituents are quite reactive with each other and with other constituents and have a relatively short lifetime ( $\sim$ hours) throughout most of the mesosphere 
Table 1. Largest 15 Solar Proton Event Periods in Past 45 Years.

\begin{tabular}{llc}
\hline Date of SPE(s) & Rank & $\begin{array}{l}\text { Computed NO } \text { Production } \\
\text { In Middle Atmosphere (Gigamoles }{ }^{1} \text { ) }\end{array}$ \\
\hline 19-27 October 1989 & 1 & 11. \\
2-10 August 1972 & 2 & 6.0 \\
14-16 July 2000 & 3 & 5.8 \\
28-31 October 2003 & 4 & 5.6 \\
5-7 November 2001 & 5 & 5.3 \\
9-11 November 2000 & 6 & 3.8 \\
24-30 September 2001 & 7 & 3.3 \\
13-26 August 1989 & 8 & 3.0 \\
23-25 November 2001 & 9 & 2.8 \\
2-7 September 1966 & 10 & 2.0 \\
15-23 January 2005 & 11 & 1.8 \\
29 September-3 October 1989 & 12 & 1.7 \\
28 January-1 February 1967 & 13 & 1.6 \\
23-29 March 1991 & 14 & 1.5 \\
7-17 September 2005 & 15 & 1.5 \\
\hline
\end{tabular}

${ }^{1}$ Gigamole $=6.02 \times 10^{32}$ atoms and molecules

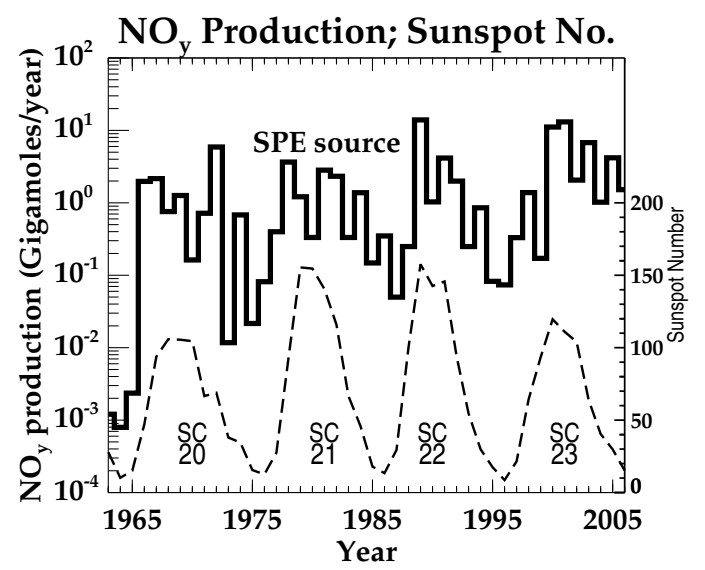

Fig. 2. The $\mathrm{NO}_{\mathrm{y}}$ production (gigamoles per year) in the middle atmosphere by SPEs is indicated by the histogram with the left ordinate showing the scale; the annual averaged sunspot numbers are indicated by the dashed line with the right ordinate showing the scale; and the number of the solar cycle (SC) is also indicated (SC 19, SC 20, SC 21, SC 22, SC 23). Plotted values for $\mathrm{NO}_{\mathrm{y}}$ production are taken from Jackman et al. (1980, 1990, 2005b), Vitt and Jackman (1996), and recent computations.

(Brasseur and Solomon, 1984, see Fig. 5.28) and thus are important only during and shortly after solar events.

\subsection{Odd nitrogen $\left(\mathrm{NO}_{\mathrm{y}}\right)$ production}

Odd nitrogen is produced when the energetic charged particles (protons and associated secondary electrons) collide with and dissociate $\mathrm{N}_{2}$. We assume that $\sim 1.25 \mathrm{~N}$ atoms are produced per ion pair and divide the proton impact of $\mathrm{N}$ atom production between ground state $(\sim 45 \%$ or $\sim 0.55$ per ion pair) and excited state $(\sim 55 \%$ or $\sim 0.7$ per ion pair) nitrogen atoms (Porter et al., 1976). Following the discussion in Jackman et al. (2005a), we assume production of 0.55 ground state $\mathrm{N}\left({ }^{4} \mathrm{~S}\right)$ atoms per ion pair and $0.7 \mathrm{~N}\left({ }^{2} \mathrm{D}\right)$ atoms per ion pair for our model simulations.

SPEs can also lead to a reduction in odd nitrogen via production of $\mathrm{N}\left({ }^{4} \mathrm{~S}\right)$, when the $\mathrm{NO}_{\mathrm{y}}$ loss reaction, $\mathrm{N}\left({ }^{4} \mathrm{~S}\right)+\mathrm{NO} \rightarrow \mathrm{N}_{2}+\mathrm{O}$, is increased. This $\mathrm{NO}_{\mathrm{y}}$ loss mechanism is important during especially large SPEs, when a huge amount of $\mathrm{NO}_{\mathrm{y}}$ is produced in a short period of time (Rusch et al., 1981). In spite of the associated enhanced loss of $\mathrm{NO}_{\mathrm{y}}$ during these disturbed periods, SPEs usually lead to a net increase in $\mathrm{NO}_{\mathrm{y}}$. Figure 2 shows a time series of our computed annually averaged global $\mathrm{NO}_{\mathrm{y}}$ production from SPEs in the middle atmosphere. The $\mathrm{NO}_{\mathrm{y}}$ production roughly follows the solar cycle with maximum (minimum) production near sunspot maximum (minimum).

Although the solar UV-induced oxidation of nitrous oxide $\left(\mathrm{N}_{2} \mathrm{O}+\mathrm{O}\left({ }^{1} \mathrm{D}\right) \rightarrow \mathrm{NO}+\mathrm{NO}\right)$ provides the largest source of $\mathrm{NO}_{\mathrm{y}}$ in the middle atmosphere (52-58 gigamoles per year; Vitt and Jackman 1996), the SPE source of $\mathrm{NO}_{\mathrm{y}}$ can be significant during certain years. This is especially true at polar latitudes where the transport from lower latitudes and the larger solar zenith angles result in a somewhat smaller local source of $\mathrm{NO}_{\mathrm{y}}$ due to $\mathrm{N}_{2} \mathrm{O}$ oxidation. Table 1 shows the magnitude of the fifteen largest individual SPEs, in terms of the computed middle atmospheric $\mathrm{NO}_{\mathrm{y}}$ production, during the past 45 years. Note that eight of these event periods occurred during the current solar cycle (1996-2007). 
The $\mathrm{NO}_{\mathrm{y}}$ family has a lifetime of months to years in the middle and lower stratosphere (e.g. Randall et al., 2001; Jackman et al., 2005a). Therefore, the effects of the SPEproduced $\mathrm{NO}_{\mathrm{y}}$ can last for several months, especially when large solar events occur in late fall or winter.

\section{Model and measurement information}

4.1 Description of the Whole Atmosphere Community Climate Model (WACCM3)

The Whole Atmosphere Community Climate Model is based on the National Center for Atmospheric Research's Community Atmospheric Model (CAM). The current version of the model, WACCM3, is derived from CAM, version 3 (CAM3), and includes all the physical parameterizations of that model. A description of CAM3 is given in Collins et al. (2004), which details the governing equations, physical parameterizations and numerical algorithms. The reader is referred to the CAM Web site (http://www.ccsm.ucar.edu/models/ atm-cam/) for more information.

WACCM3 has fully interactive dynamics, radiation, and chemistry. WACCM3 not only incorporates modules from CAM3, but also the Thermosphere-Ionosphere-MesosphereElectrodynamics General Circulation Model (TIME-GCM) and the Model for OZone And Related chemical Tracers (MOZART-3). WACCM3 is a global model and has 66 vertical levels from the ground to $4.5 \times\left(10^{-6}\right) \mathrm{hPa}$ (approximately $145 \mathrm{~km}$ geometric altitude). Vertical resolution is $\leq 1.5 \mathrm{~km}$ between the surface and about $25 \mathrm{~km}$. Above that altitude, vertical resolution increases slowly to $2 \mathrm{~km}$ at the stratopause and $3.5 \mathrm{~km}$ in the mesosphere; beyond the mesopause, the vertical resolution is one half the local scale height. The latitude and longitude grids have spacing of $4^{\circ}$ and $5^{\circ}$, respectively.

WACCM3 incorporates most of the CAM3 ingredients, however, its gravity wave drag and vertical diffusion parameterizations are modified somewhat and described in Garcia et al. (2007). WACCM3 differs from CAM3 in other ways in that it includes a detailed neutral chemistry model for the middle atmosphere; heating due to chemical reactions; a model of ion chemistry in the mesosphere/lower thermosphere (MLT); ion drag and auroral processes; and parameterizations of shortwave heating at extreme ultraviolet (EUV) wavelengths and infrared transfer under nonlocal thermodynamic equilibrium (NLTE) conditions. WACCM3's neutral chemistry module including reactions and solver is described in Kinnison et al. (2007). The neutral constituent photochemical reaction rates and photodissociation cross sections are taken from Sander et al. (2003). As a full GCM with chemistry, WACCM3 implicitly includes the diurnal cycle for all constituents at all levels in the model's domain. The other processes and parameterizations, which are unique to WACCM3, are described in Garcia et al. (2007). Other de- tails about WACCM3 and model results are given in Sassi et al. (2002, 2004), Forkman et al. (2003), Richter and Garcia (2006), and Marsh et al. (2007).

\subsection{WACCM3 simulations}

WACCM3 was forced with observed time-dependent sea surface temperatures (SSTs), observed solar spectral irradiance and geomagnetic activity changes, and observed concentrations of greenhouse gases and halogen species over the simulation periods (see Garcia et al., 2007). We have completed a number of WACCM3 simulations, either with or without the daily ionization rates from SPEs. The ionization rates, when included, were applied uniformly over both polar cap regions (60-90 $0^{\circ} \mathrm{N}$ and $60-90^{\circ} \mathrm{S}$ geomagnetic latitude) as solar protons are guided by the Earth's magnetic field lines to these areas (McPeters et al., 1981; Jackman et al., 2001, 2005a). The effects are not expected to be symmetric between the hemispheres because of the differing offsets of geomagnetic and geographic poles. Other differences between the hemispheres are primarily driven by seasonal differences in the northern and southern polar regions. Transport and solar angle disparities due to seasonal changes are the main causes of these inter-hemispheric variances.

A list of the WACCM3 simulations and their designation in this study is given in Table 2 . Usually an ensemble consisting of four simulations with different initial conditions was run for each experiment. Simulation 1(a, b, c, d) with SPEs covered the full period 1 January 1963-31 December 2005. Since the year 1989 was very active in terms of SPEs (see Table 1), simulations with SPEs (see $2 \mathrm{a}, \mathrm{b}, \mathrm{c}, \mathrm{d}$ ) and without SPEs (see $2 \mathrm{w}, \mathrm{x}, \mathrm{y}, \mathrm{z}$ ) were performed to study the 16 month period, 1 January 1989-30 April 1990. The very large July 2000 SPE was studied in further detail over the period 2 July-30 September 2000 using simulations with SPEs (see $3 \mathrm{a}, \mathrm{b}, \mathrm{c}, \mathrm{d}$ ) and without SPEs (see 3w, x, y, z). The very large late October/early November 2003 SPEs were studied in further detail over the period 25 October-14 November 2003 using a simulation with SPEs (see $4 a$ ) and without SPEs (see $4 w)$. Simulations $5(w, x, y, z)$ without SPEs run over the period 2 July 2000-31 December 2004 provided necessary daily information for computing the statistical significance of the WACCM3 results as a function of latitude and altitude. Throughout the paper we discuss $2 \sigma$ statistical significance levels to illustrate how the SPE effects compares to the background variability simulated in the model.

Simulations 1(a, b, c, d), 2(a, b, c, d), and 2(w, x, y, z) have model output every five days. Simulations $3(a, b, c, d)$, 3(w, x, y, z), 4(a), 4(w), and 5(w, x, y, z) have model output every day. For short periods ( $\sim$ two weeks), different realizations produce similar results; thus it is appropriate to use only a single realization for simulation 4. WACCM3 output, whether daily or every five days, is a snap-shot of model results at 00:00 GMT. 
Table 2. Description of WACCM3 simulations.

\begin{tabular}{llll}
\hline $\begin{array}{l}\text { Simulation } \\
\text { designation }\end{array}$ & $\begin{array}{l}\text { Number of } \\
\text { realizations }\end{array}$ & $\begin{array}{l}\text { Time } \\
\text { period }\end{array}$ & $\begin{array}{l}\text { SPEs } \\
\text { included }\end{array}$ \\
\hline 1 (a, b, c, d) & 4 & 1963-2005 & Yes \\
2(a, b, c, d) & 4 & $\begin{array}{l}\text { 1 January 1989-30 April 1990 } \\
\text { 1 January 1989-30 April 1990 }\end{array}$ & $\begin{array}{l}\text { Yes } \\
\text { No }\end{array}$ \\
(w, x, y, z) & 4 & 2 July-30 September 2000 & Yes \\
$3(\mathrm{a}, \mathrm{b}, \mathrm{c}, \mathrm{d})$ & 4 & 2 July-30 September 2000 & No \\
$3(\mathrm{w}, \mathrm{x}, \mathrm{y}, \mathrm{z})$ & 4 & 25 October-14 November 2003 & Yes \\
$4(\mathrm{a})$ & 1 & 25 October-14 November 2003 & \\
$4(\mathrm{w})$ & 1 & 2 July 2000-31 December 2004 & No \\
\hline 5(w, x, y, z) & 4 & & \\
\hline
\end{tabular}

\subsection{Satellite instrument measurements}

Several satellite instruments have recorded atmospheric constituent change caused by SPEs. We will compare WACCM3 results with:

1. Nimbus 4 Backscatter Ultraviolet (BUV) ozone measurements (August 1972 SPEs);

2. Stratospheric Aerosol and Gas Experiment (SAGE) II ozone and $\mathrm{NO}_{2}$ and NOAA 11 Solar Backscatter Ultraviolet 2 (SBUV/2) ozone measurements (October 1989 SPEs);

3. NOAA 14 SBUV/2 ozone and Upper Atmosphere Research Satellite (UARS) Halogen Occultation Experiment (HALOE) $\mathrm{NO}_{\mathrm{x}}$ (July $\left.2000 \mathrm{SPE}\right)$;

4. UARS HALOE $\mathrm{NO}_{\mathrm{x}}$ and Envisat Michelson Interferometer for Passive Atmospheric Sounding (MIPAS) ozone, $\mathrm{NO}_{\mathrm{x}}, \mathrm{HNO}_{3}, \mathrm{~N}_{2} \mathrm{O}_{5}, \mathrm{ClONO}_{2}, \mathrm{HOCl}$, and $\mathrm{ClO}$ (October/November 2003 SPEs). The MIPAS ozone, $\mathrm{NO}_{2}, \mathrm{HNO}_{3}, \mathrm{~N}_{2} \mathrm{O}_{5}, \mathrm{ClONO}_{2}$, and $\mathrm{ClO}$ are reprocessed data versions of those previously published in LópezPuertas et al. (2005a, b) and von Clarmann et al. (2005) providing, except for $\mathrm{ClO}$, higher altitude resolution.

\section{SPE-induced short-term (days) changes in composi- tion}

The very large SPEs (see Table 1) caused the most profound changes in atmospheric composition. Satellite instrument observations exist for several constituents during SPEs that occurred in solar cycle 23. The October 2003, July 2000, August 1972, and October 1989 SPEs - the fourth, third, second, and first largest SPE periods in the past 45 years, respectively - were ideal candidates for comparing WACCM3 results to measurements. Previous studies of these four SPE periods have documented significant changes associated with the events (e.g. Heath et al., 1977; Reagan et al., 1981; McPeters et al., 1981; Jackman and McPeters, 1987, 2004; Jackman et al., 1990, 1993, 1995, 2001, 2005a; Zadorozhny et al., 1992; Randall et al., 2001; Seppala et al., 2004; Degenstein et al., 2005; López-Puertas et al., 2005a, b; Orsolini et al., 2005; von Clarmann et al., 2005; Rohen et al., 2005). We compare the WACCM3 results with some of these satellite measurements in Sects. 5.2 through 5.4.

Several large solar eruptions occurred in October/November 2003, the so-called "Halloween Storms". The most intense SPE period accompanying these solar eruptions was during 28-31 October 2003, the fourth largest SPE period in the past 45 years. The short-term atmospheric effects from these SPEs are probably the best documented for any solar events. At least five satellite instruments measured the atmospheric effects of these SPEs, including UARS HALOE, NOAA-16 SBUV/2, and Envisat's MIPAS, SCIAMACHY, and GOMOS (Seppala et al., 2004; Jackman et al., 2005a; López-Puertas et al., 2005a, b; von Clarmann et al., 2005; Orsolini et al., 2005; Degenstein et al., 2005; Rohen et al., 2005). The middle atmospheric effects from the SPEs were largest during and several days after these events.

To be clear: We focus only on the impact of the solar protons associated with the solar eruptions in OctoberNovember 2003. It is likely that huge increases in lower thermospheric $\mathrm{NO}_{\mathrm{x}}$ were created by lower-energy electron precipitation, which occurred in conjunction with these SPEs. The very large enhancements in mesospheric and upper stratospheric $\mathrm{NO}_{\mathrm{x}}$ observed by UARS HALOE, the Canadian Space Agency (CSA) Atmospheric Chemistry Experiment (ACE), and MIPAS in the Northern Hemisphere in February-April 2004 were possibly caused by the downward transport of this thermospheric $\mathrm{NO}_{\mathrm{x}}$ to lower atmospheric 

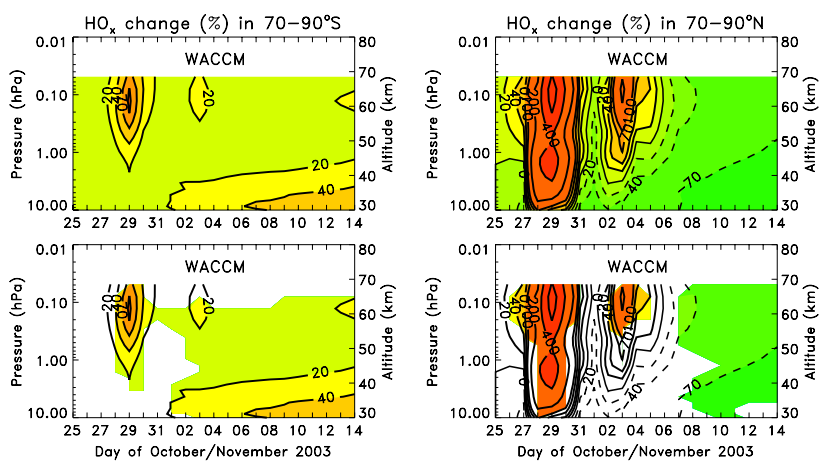

Fig. 3. Temporal evolution of $\mathrm{HO}_{\mathrm{x}}\left(\mathrm{H}, \mathrm{OH}, \mathrm{HO}_{2}\right)$ abundance changes relative to 25 October during and after the OctoberNovember 2003 SPEs for the Southern Hemisphere (70-90 S) (top left) and Northern Hemisphere $\left(70-90^{\circ} \mathrm{N}\right)$ (top right) polar caps predicted by WACCM simulation 4(a). Contour levels plotted are $-70,-40,-20,0,20,40,70,100,200,400$, and 700\%. Bottom plots are the top plots repeated with the colored areas indicating the regions which are statistically significant at the $2 \sigma$ level.

levels (Natarajan et al., 2004; Rinsland et al., 2005, and Randall et al., 2005).

\section{$5.1 \mathrm{HO}_{\mathrm{x}}\left(\mathrm{H}, \mathrm{OH}, \mathrm{HO}_{2}\right)$ constituents}

The "Halloween Storms" of 2003 caused SPEs, which produced $\mathrm{HO}_{\mathrm{x}}$ constituents. The $\mathrm{HO}_{\mathrm{x}}$ changes simulated by WACCM 3 are presented in Fig. 3 for the southern $\left(70-90^{\circ} \mathrm{S}\right.$; top left) and northern $\left(70-90^{\circ} \mathrm{N}\right.$; top right) polar regions from simulation 4 (a). Statistically significant $2 \sigma$ changes are shown in the colored areas in the bottom two plots of Fig. 3 for the same latitude regions. Huge $\mathrm{HO}_{\mathrm{x}}$ increases are predicted during the most intense periods of the SPEs reaching over $100 \%$ and $700 \%$ near $0.1 \mathrm{hPa}$ in the southern and northern polar regions, respectively. Although the SPEproduced $\mathrm{HO}_{\mathrm{x}}$ concentrations are roughly the same in both hemispheres, the percentage change in $\mathrm{HO}_{\mathrm{x}}$ shows a huge interhemispheric difference. This interhemispheric $\mathrm{HO}_{\mathrm{x}}$ enhancement difference is a result of the ambient levels of $\mathrm{HO}_{\mathrm{x}}$ which are greater in the southern hemisphere (e.g., see Solomon et al., 1983) due to the different solar zenith angles and hence greater $\mathrm{HO}_{\mathrm{x}}$ production relative to the $\mathrm{NH}$.

Since the $\mathrm{HO}_{\mathrm{x}}$ species have a relatively short lifetime (hours), these very short-term effects disappear almost entirely by the end of 6 November. $\mathrm{HO}_{\mathrm{x}}$ changes after this date are due to the normal seasonal behavior in those regions as sunlight increases (decreases) in the southern (northern) polar regions, leading to increases (decreases) in the sources of $\mathrm{HO}_{\mathrm{x}}\left[\mathrm{H}_{2} \mathrm{O}+\mathrm{O}\left({ }^{1} \mathrm{D}\right) \rightarrow 2 \mathrm{OH}\right.$ and $\left.\mathrm{H}_{2} \mathrm{O}+\mathrm{h} \nu \rightarrow \mathrm{H}+\mathrm{OH}\right]$. The enhanced $\mathrm{HO}_{\mathrm{x}}$ constituents produced by the SPEs led to shortterm ozone destruction, especially in the mesosphere and upper stratosphere. This will be discussed in Sect. 5.3.
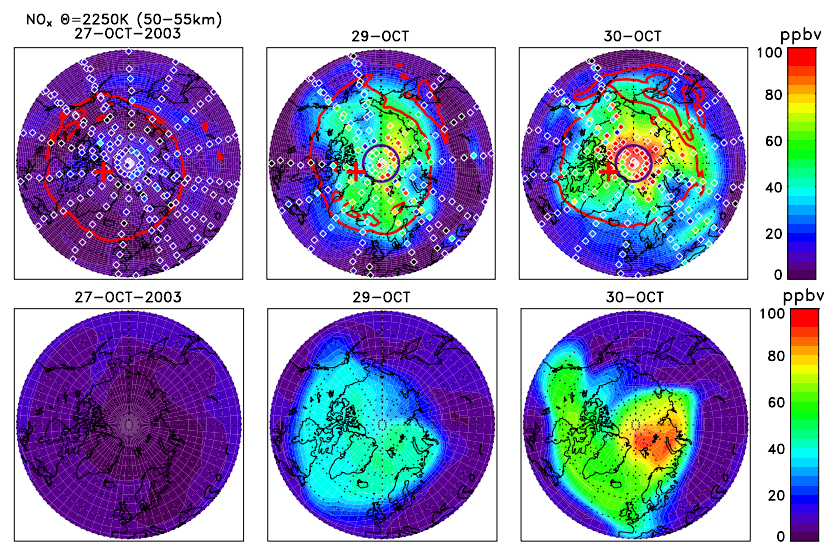

Fig. 4. Top three plots are taken from Fig. 2 of López-Puertas et al. (2005a) and show the Northern Hemisphere polar atmospheric abundance of $\mathrm{NO}_{\mathrm{x}}$ (ppbv) for days 27, 29, and 30 October 2003, which is just before and during a major solar proton event at a potential temperature of $2250 \mathrm{~K}$. Contours are zonally smoothed within $700 \mathrm{~km}$. Individual measurements are represented by diamonds. The polar vortex edge is represented with a red curve and the geomagnetic pole is marked with a red plus sign. The circle around the pole represents the polar night terminator. Bottom three plots are from WACCM3 simulation 4(a) for the same three days at $0.55 \mathrm{hPa}(\sim 55 \mathrm{~km})$.

\section{2 $\mathrm{NO}_{\mathrm{x}}\left(\mathrm{N}, \mathrm{NO}, \mathrm{NO}_{2}\right)$ constituents}

The $\mathrm{NO}_{\mathrm{x}}$ species have considerably longer lifetimes than the $\mathrm{HO}_{\mathrm{x}}$ species and are produced in great abundance during very large SPEs. For example, we have evidence of huge enhancements of $\mathrm{NO}_{\mathrm{x}}$ as a result of the "Halloween Storms" of 2003. The Envisat MIPAS instrument provided simultaneous observations of $\mathrm{NO}_{\mathrm{x}}$ in both polar regions. Atomic nitrogen $(\mathrm{N})$ is quite small in the mesosphere and stratosphere; thus, the MIPAS measurements of $\mathrm{NO}$ and $\mathrm{NO}_{2}$ essentially provide a measure of the polar $\mathrm{NO}_{\mathrm{x}}$ enhancements during the "Halloween Storms" of 2003. We show the MIPAS Northern Hemisphere polar $\mathrm{NO}_{\mathrm{x}}$ on three days $(27,29$, and 30 October) in Fig. 4 (top) at the $2250 \mathrm{~K}(50-55 \mathrm{~km})$ surface. The polar vortex edge has been calculated using the criteria discussed in Nash et al. (1996) but modified so that a long-lived chemical constituent influenced by dynamics $\left(\mathrm{CH}_{4}\right.$ below $1500 \mathrm{~K}$ and $\mathrm{CO}$ above $)$ has been used, instead of the mean zonal winds. That is, the vortex edge is defined where there coexists a pronounced gradient in potential vorticity and a large gradient in the dynamically-influenced constituent. This vortex boundary is represented with a red curve and the geomagnetic pole is marked with a red plus sign. Some individual $\mathrm{NO}_{\mathrm{x}}$ values reached $180 \mathrm{ppbv}$, about a factor of ten larger than normal under unperturbed conditions. Generally, the largest average $\mathrm{NO}_{\mathrm{x}}$ values were close to $100 \mathrm{ppbv}$. 

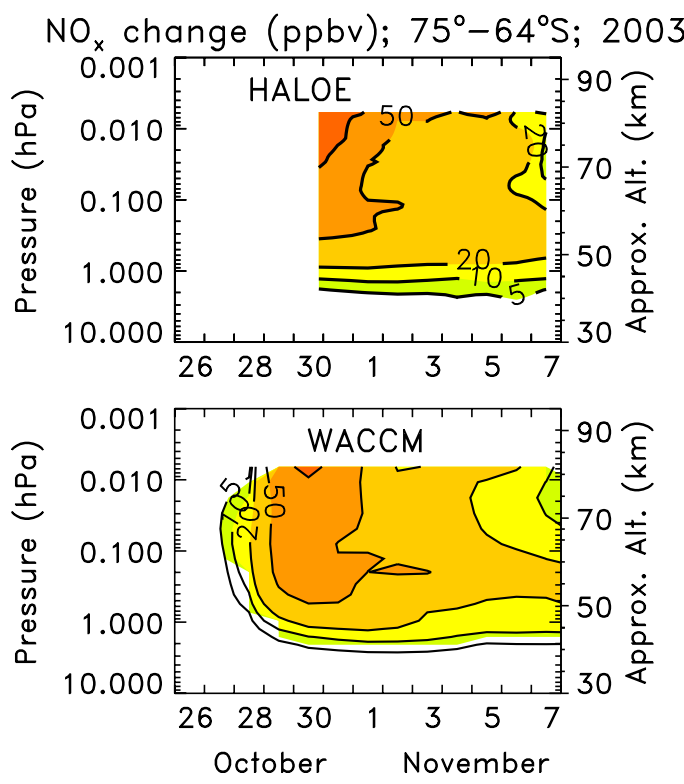

Fig. 5. Top plot is adapted from Fig. 7 of Jackman et al. (2005a) and shows the daily average HALOE sunset-measured polar Southern Hemisphere $\mathrm{NO}_{\mathrm{x}}$ change caused by the late October-early November 2003 SPEs beyond the ambient atmosphere amounts measured 12-15 October 2003. The HALOE measurements were at latitudes between $64^{\circ}$ and $75^{\circ} \mathrm{S}$. Bottom plot is derived from WACCM3 simulation 4(a) in a similar way and indicates the $\mathrm{NO}_{\mathrm{x}}$ change caused by the October-November 2003 SPEs beyond the ambient atmosphere amounts on 25 October (before the SPEs). Contour levels plotted are 5, 10, 20, 50, and 100 ppbv. The colored region indicates statistically significant changes at the $2 \sigma$ level in the bottom plot.

We present WACCM3 results for the same three days in Fig. 4 (bottom) from simulation 4(a). The model shows similar qualitative and quantitative behavior with polar $\mathrm{NO}_{\mathrm{x}}$ levels reaching over 90 ppbv. There are differences in the shape of the SPE-perturbed region, which are probably due to differences between the transport in WACCM3 and the Earth's atmosphere at this level. WACCM3 is a free-running climate model, so the computations cannot be expected to reproduce in detail the conditions prevailing in the atmosphere at any particular time.

$\mathrm{NO}_{\mathrm{x}}$ levels were also measured during this period by UARS HALOE. We show the excess $\mathrm{NO}_{\mathrm{x}}$ beyond baseline amounts before the SPE period in Fig. 5 (top) (adapted from Fig. 7 of Jackman et al., 2005a). This plot was constructed with HALOE sunset profiles taken at high southern latitudes $\left(64^{\circ}\right.$ and $\left.75^{\circ} \mathrm{S}\right)$ in the SPE-disturbed period 30 October-7 November 2003 differenced with those sunrise profiles taken at high southern latitudes before the SPE (12-15 October 2003). Since $\mathrm{NO}$ and $\mathrm{NO}_{2}$ are tightly coupled and the quantity $\mathrm{NO}+\mathrm{NO}_{2}$ is highly conserved during a $24-\mathrm{h}$ period in the upper stratosphere and mesosphere, it is possible to com-

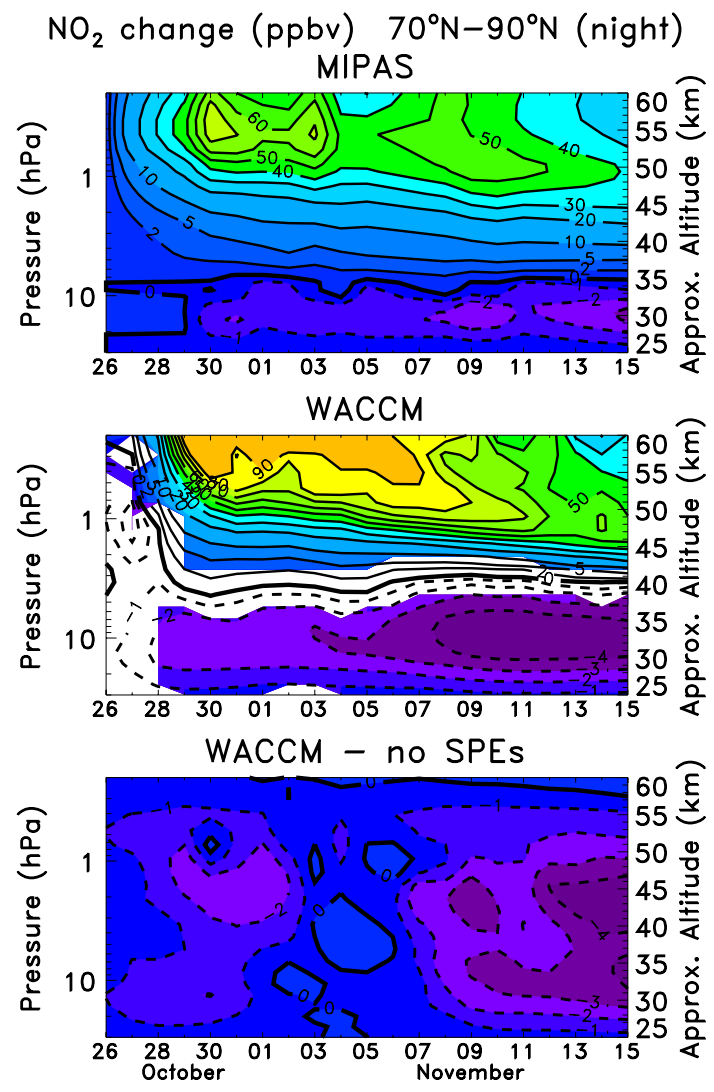

Fig. 6. Temporal evolution of nighttime $\mathrm{NO}_{2}$ abundance changes relative to 26 October for the polar Northern Hemisphere (70$90^{\circ} \mathrm{N}$ ) from MIPAS with the reprocessed version $\mathrm{V} 3 \mathrm{O} \_\mathrm{NO}_{2} \_$data (top). Middle plot is derived from WACCM3 simulation 4(a), which includes SPEs, and indicates nighttime $\mathrm{NO}_{2}$ changes relative to 25 October in $70-90^{\circ} \mathrm{N}$. The colored areas in the middle plot demonstrate the $2 \sigma$ statistically significant regions. Bottom plot is derived from WACCM3 simulation 4(w), which does not include SPEs, and indicates $\mathrm{NO}_{2}$ seasonal changes relative to 25 October for night in $70-90^{\circ} \mathrm{N}$. Contour levels plotted are $-4,-3,-2,-1,0,2,5,10,20$, $30,40,50,60,70,80$, and 90 ppbv.

pare sunrise $\mathrm{NO}_{\mathrm{x}}$ measurements with sunset $\mathrm{NO}_{\mathrm{x}}$ measurements and derive the perturbed atmospheric $\mathrm{NO}_{\mathrm{x}}$ changes for a short period (approximately a week).

We present WACCM3 results from simulation 4(a) for $\mathrm{NO}_{\mathrm{x}}$ during this same period in Fig. 5 (bottom). The WACCM3 results are zonal average values over the same latitude band as HALOE. These model/measurement comparisons are valid because the $\mathrm{NO}_{\mathrm{x}}$ family changes so slowly with time. The values in the plot show the excess $\mathrm{NO}_{\mathrm{x}}$ beyond the 25 October 2003 levels (quiet period). The colored region indicates $2 \sigma$ statistically significant changes. Both the observations and the model indicate a very similar temporal structure. Huge $\mathrm{NO}_{\mathrm{x}}$ increases of greater than $100 \mathrm{ppbv}$ (red color) were produced in the middle to upper mesosphere $(0.03$ to $0.006 \mathrm{hPa})$ for $30-31$ October. The lower mesosphere showed $\mathrm{NO}_{\mathrm{x}}$ increases of greater than $20 \mathrm{ppbv}$ 
throughout the period, compared with unperturbed values of less than $1 \mathrm{ppbv}$ (Jackman et al., 2005a). There are some modest differences between the WACCM3 predictions and the HALOE measurements. However, given the huge $\mathrm{NO}_{\mathrm{x}}$ changes from this perturbation, WACCM3 and HALOE are in reasonable agreement.

The nighttime NH MIPAS $\mathrm{NO}_{2}$ enhancements are compared with WACCM3 results in Fig. 6. The reprocessed MIPAS version $\mathrm{V} 3 \mathrm{O} \_\mathrm{NO}_{2}-9$ data are given here. WACCM3 simulation 4(a) (Fig. 6, middle) shows $\mathrm{NO}_{2}$ increases over 90 ppbv and MIPAS (Fig. 6, top) observes maximum $\mathrm{NO}_{2}$ increases of about $70 \mathrm{ppbv}$ in the lower mesosphere. The enhanced $\mathrm{NO}_{2}$ is long-lasting with amounts greater than $30 \mathrm{ppbv}$ in both MIPAS and WACCM3 between 45 and $55 \mathrm{~km}$ through 14 November. The downward transport of $\mathrm{NO}_{2}$ over this time period is also evident in both MIPAS and WACCM3. Figure 6 (bottom) shows WACCM3 results from a simulation without SPEs, simulation $4(\mathrm{w})$, which indicates that the seasonal changes are generally negative at this time of year. The colored areas Fig. 6 (middle) illustrate the regions where the perturbation is statistically significant at the $2 \sigma$ level. For these altitudes nighttime $\mathrm{NO}_{2}$ is essentially $\mathrm{NO}_{\mathrm{x}}$. The WACCM3 results qualitatively agree with MIPAS. However, WACCM3 is generally larger than MIPAS (usually $15 \mathrm{ppbv}$ or more) at most altitudes above $45 \mathrm{~km}$. From $35-45 \mathrm{~km}$ MIPAS mostly measures higher levels of $\mathrm{NO}_{2}$ enhancement than predicted. Below $35 \mathrm{~km}$ both MIPAS and WACCM3 show seasonal $\mathrm{NO}_{2}$ decreases.

\subsection{Ozone}

Ozone was also impacted by these SPEs. The SPE-produced $\mathrm{HO}_{\mathrm{x}}$ and $\mathrm{NO}_{\mathrm{x}}$ constituents led to short- and longer-term catalytic ozone destruction in the lower mesosphere and stratosphere (pressures greater than about $0.5 \mathrm{hPa}$ ). The temporal evolution of changes in ozone abundance measured by MIPAS during and after the October-November 2003 SPEs is given in Fig. 7 (top). These values are presented for the Southern Hemisphere (SH) $\left(70-90^{\circ} \mathrm{S}\right)$ and Northern Hemisphere $(\mathrm{NH})\left(70-90^{\circ} \mathrm{N}\right)$ polar caps. The reprocessed MIPAS version V3O_O__ 3 9 data are shown here. The measurements are compared to WACCM3 predictions from simulation 4(a) in the same regions in Fig. 7 (upper middle). Due to the short lifetime of $\mathrm{HO}_{\mathrm{x}}$ constituents (see Fig. 3), their ozone influence lasts only during and for a few hours after the SPEs. This explains the huge measured and modeled ozone depletion above $50 \mathrm{~km}$ on $29-30$ October and, to a lesser extent, on 3-4 November. Note that Fig. 1 shows ion pair production, which is essentially a proxy for the $\mathrm{NO}_{\mathrm{x}}$ and $\mathrm{HO}_{\mathrm{x}}$ production. WACCM3 predictions in Fig. 7 (lower middle) are the same as Fig. 7 (upper middle) except the colored areas illustrate the regions where the perturbation is statistically significant at the $2 \sigma$ level. Figure 7 (bottom) shows WACCM3 results from a simulation without SPEs, simulation $4(\mathrm{w})$, indicating the seasonal changes at this time of year.

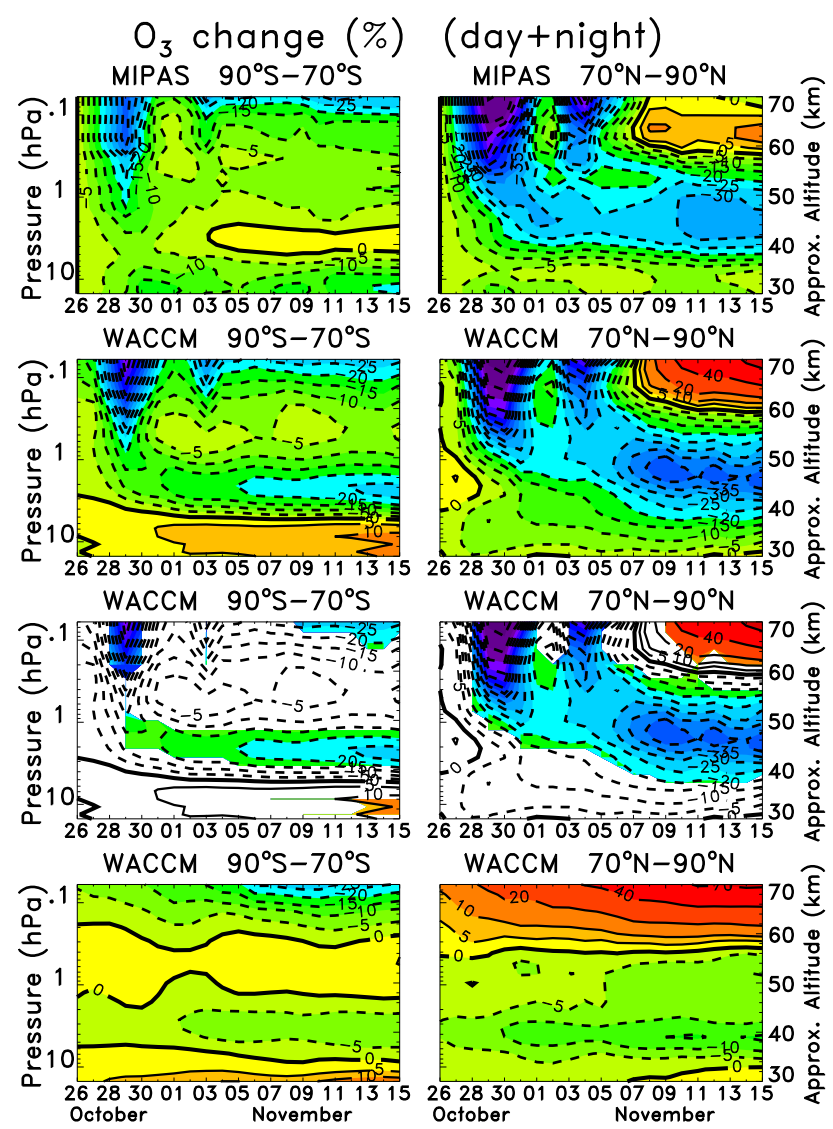

Fig. 7. Top two plots are similar to Fig. 4 of López-Puertas et al. (2005a) but with the reprocessed MIPAS version V3O_O ${ }_{3}-9$ data and show the temporal evolution of changes in ozone relative to 25 October during and after the October-November 2003 SPEs for the Southern Hemisphere (SH) $\left(70-90^{\circ} \mathrm{S}\right)$ (left) and Northern Hemisphere $(\mathrm{NH})\left(70-90^{\circ} \mathrm{N}\right)$ (right) polar caps. Upper middle two plots are derived from WACCM3 simulation 4(a) and indicate ozone changes relative to 25 October. Lower middle two plots are the same as the upper middle two plots except the colored areas demonstrate the $2 \sigma$ statistically significant regions. Bottom plots are derived from WACCM3 simulation 4(w), which does not include SPEs, and indicates ozone seasonal changes relative to 25 October. Contour levels plotted are $-70,-65,-60,-55,-50,-45,-40,-35,-30,-25$, $-20,-15,-10,-5,0,5,10,20$, and $40 \%$.

SPE impacts in the NH are larger than the SH in both models and simulations. NH ozone depletion exceeds $50 \%$ during the SPEs in late October. These interhemispheric differences in ozone depletion are caused by the differences in solar zenith angle between the $\mathrm{NH}$ and $\mathrm{SH}$. The $\mathrm{NH}$ with the larger solar zenith angle has a larger percentage $\mathrm{HO}_{\mathrm{x}}$ change (see Fig. 3) than the SH and thus a larger short-term impact on ozone (for further discussion see Solomon et al., 1983). Polar NH upper stratospheric ozone depletion greater than $30 \%$ continues through 14 November, the end of the plotting period. The polar $\mathrm{SH}$ shows ozone reduction greater 


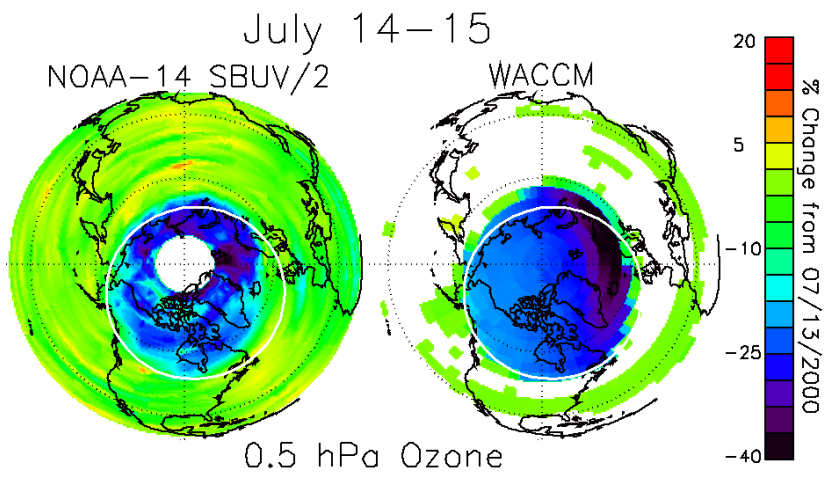

Fig. 8. Left plot shows NOAA-14 SBUV/2 Northern Hemisphere polar ozone percentage change at $0.5 \mathrm{hPa}$ from $13 \mathrm{July} 2000$ (before the SPE) to 14-15 July 2000 (maximum proton intensity). Right plot shows WACCM3 "snapshot" using simulation 3(a) of polar ozone percentage change at $0.5 \mathrm{hPa}$ for 00:00 GMT from 13 July to 15 July 2000 . The colored areas in the right plot demonstrate the $2 \sigma$ statistically significant regions.

than $30 \%$ during the SPEs in late October with lower mesospheric ozone depletion from 5-10\% continuing through 14 November.

The measured and modeled ozone depletions show some differences. The NH modeled ozone indicates a larger recovery (ozone enhancement) above $\sim 57 \mathrm{~km}$ after 7 November, than indicated in the measurements. This apparent $\mathrm{NH}$ ozone recovery is due to seasonal changes (see bottom plots in Fig. 7), wherein ozone is enhanced via transport from above. The SH modeled ozone below $\sim 45 \mathrm{~km}$ indicates a larger ozone depletion after 2 November, than indicated in the measurements. The reason(s) behind these $\mathrm{NH}$ and $\mathrm{SH}$ model-measurement differences are still unclear, but is probably caused in part by the fact that transport and temperature in WACCM do not correspond to any specific year.

Other measurements of short-term ozone loss caused by solar protons are available for other SPEs. For example, a very large SPE commenced on 14 July 2000, the so-called "Bastille Day" solar storm, which was the third largest SPE period in the past 45 years. This SPE took place over the 14-16 July period. Jackman et al. (2001) showed Northern Hemisphere polar ozone changes (in ppmv) from the NOAA $14 \mathrm{SBUV} / 2$ instrument at $0.5 \mathrm{hPa}$ due to the July $2000 \mathrm{SPE}$ between 13 July (before SPE) and 14-15 July (during SPE), 2000. We provide a similar plot in Fig. 8, which shows the percentage change for ozone from 13 July to 14-15 July for NOAA 14 SBUV/2 and from 13 July to 15 July at 0:00 GMT from the average of WACCM3 simulations $3(a, b, c, d)$. Figure 8 (left) is constructed from $24 \mathrm{~h}$ of NOAA 14 SBUV/2 orbital data during the maximum intensity of the event and Fig. 8 (right) is a difference of model "snapshots." The colored areas in Fig. 8 (right) demonstrate the $2 \sigma$ statistically significant changes.
The polar cap edge $\left(60^{\circ}\right.$ geomagnetic latitude), wherein the protons are predicted to interact with the atmosphere, is indicated by the white circle. Large ozone decreases of $30-40 \%$ are seen at this pressure level in both the SBUV/2 observations and WACCM3 calculations, which are primarily caused by the SPE. These ozone decreases are driven by catalytic destruction from the $\mathrm{HO}_{\mathrm{x}}$ increases of $\sim 100 \%$ and are mostly confined to the polar cap areas (e.g. Jackman et al., 2001). The polar cap changes are nearly all statistically significant at $2 \sigma$. Overall there is good agreement between WACCM3 and SBUV/2.

\subsection{Other constituents}

Several other constituents appear to have been influenced as a result of the SPEs during the "Halloween Storms" of 2003, including $\mathrm{HNO}_{3}, \mathrm{~N}_{2} \mathrm{O}_{5}, \mathrm{ClONO}_{2}, \mathrm{HOCl}$, and $\mathrm{ClO}$ (Orsolini et al., 2005; von Clarmann et al., 2005; López-Puertas et al., 2005b). Here we show WACCM3 comparisons with all of these constituents.

\subsection{1 $\mathrm{HNO}_{3}$ change}

Figure 9 (top) shows the temporal change in Envisat MIPAS $\mathrm{V} 3 \mathrm{O} \mathrm{HNO}_{3}-9$ measurements of $\mathrm{HNO}_{3}$ during the nighttime in the polar Northern Hemisphere $\left(70-90^{\circ} \mathrm{N}\right)$. LópezPuertas et al. (2005b) argued that the observed $\mathrm{HNO}_{3}$ increases in the upper stratosphere and lower mesosphere were probably primarily caused by the gas-phase reaction, $\mathrm{NO}_{2}+\mathrm{OH}+\mathrm{M} \rightarrow \mathrm{HNO}_{3}+\mathrm{M}$. Both $\mathrm{OH}$ and $\mathrm{NO}_{2}$ enhancements were simulated when WACCM3 was run with SPEs and the inclusion of this reaction in WACCM3 led to increases in $\mathrm{HNO}_{3}$.

We show WACCM3 results in Fig. 9 for two types of representation: 1) usual representation on the model grid, called WACCM; and 2) after application of the MIPAS averaging kernel (AK), called WACCM (AK). This second representation can significantly change the model results for constituents $\mathrm{HNO}_{3}, \mathrm{~N}_{2} \mathrm{O}_{5}, \mathrm{ClONO}_{2}, \mathrm{HOCl}$, and $\mathrm{ClO}$, but is of minor influence on the WACCM3/MIPAS ozone comparisons (Fig. 7). MIPAS retrievals are based on constrained least squares fitting of modeled to measured spectra (von Clarmann et al., 2003). The applied constraint smooths the vertical profiles and affects the retrieval particularly at altitudes where MIPAS is not very sensitive to the emission of the particular constituent. The model and MIPAS data are more comparable when the MIPAS AKs are applied to the WACCM data (Rodgers, 2000). The result WACCM (AK) is what MIPAS would see if it would sound the atmospheric state as modeled by WACCM.

The usual representation of model results from simulation 4(a) (see Fig. 9, middle left) suggest that $\mathrm{HNO}_{3}$ increases were largest above $45 \mathrm{~km}$ and below $30 \mathrm{~km}$ in the period plotted. The sampling of simulation 4(a) results with the MIPAS AK moves the peak of the $\mathrm{HNO}_{3}$ increases to 
a lower altitude (by a few $\mathrm{km}$ ), reduces the peak amounts, and does not significantly improve the model/measurement agreement. The colored areas in Fig. 9 (middle plots) illustrate the regions where the perturbation simulated in WACCM3 is statistically significant at the $2 \sigma$ level. Figure 9 (bottom plots) shows WACCM3 results from a simulation without SPEs, simulation 4(w), which indicates that there are seasonal changes, but none that are very important above $35 \mathrm{~km}$.

It is difficult to understand the large observed changes in the $35-55 \mathrm{~km}$ altitude range which are not simulated in WACCM3, given the ionization rates of Fig. 1, without involving some other pathway for $\mathrm{HNO}_{3}$ production such as ion chemistry. López-Puertas et al. (2005b) discussed the following ion chemistry scheme for $\mathrm{HNO}_{3}$ production:

$$
\begin{aligned}
& \mathrm{O}_{2}^{+} \mathrm{H}_{2} \mathrm{O}+\mathrm{H}_{2} \mathrm{O} \rightarrow \mathrm{H}_{3} \mathrm{O}^{+} \cdot \mathrm{OH}+\mathrm{O}_{2} \\
& \mathrm{H}_{3} \mathrm{O}^{+} \cdot \mathrm{OH}+\mathrm{H}_{2} \mathrm{O} \rightarrow \mathrm{H}^{+} \cdot\left(\mathrm{H}_{2} \mathrm{O}\right)_{2}+\mathrm{OH} \\
& \mathrm{H}^{+} \cdot\left(\mathrm{H}_{2} \mathrm{O}\right)_{2}+\mathrm{NO}_{3}^{-} \rightarrow \mathrm{HNO}_{3}+\mathrm{H}_{2} \mathrm{O}+\mathrm{H}_{2} \mathrm{O}
\end{aligned}
$$

$$
\mathrm{Net}: \mathrm{H}_{2} \mathrm{O}+\mathrm{NO}_{3} \rightarrow \mathrm{HNO}_{3}+\mathrm{OH}
$$

This pathway for $\mathrm{HNO}_{3}$ production, first proposed by Solomon et al. (1981), requires the production of $\mathrm{NO}_{3}^{-}$and functions under dark conditions. Although ion chemistry involving $\mathrm{N}_{2}^{+}, \mathrm{O}_{2}^{+}, \mathrm{N}^{+}, \mathrm{NO}^{+}, \mathrm{O}^{+}$, and electrons is included in WACCM3, ion reactions involving water are presently not included. It is beyond the scope of this paper to include such a water cluster ion scheme for $\mathrm{HNO}_{3}$ production. Another possible reason behind the model/measurement discrepancy could be a faster reaction rate for $\mathrm{NO}_{2}+\mathrm{OH}+\mathrm{M} \rightarrow \mathrm{HNO}_{3}+\mathrm{M}$ than was given in Sander et al. (2003) and employed in WACCM3.

The enhanced $\mathrm{HNO}_{3}$ measured by MIPAS during the peak of the solar event is rather temporary with a peak over 2.5 ppbv on 29-31 October 2003 between 42 and $50 \mathrm{~km}$ decreasing rapidly to less than 0.4 ppbv by 8 November 2003 and increasing again to greater than 0.8 ppbv by 15 November 2003. Although the latter MIPAS $\mathrm{HNO}_{3}$ enhancement (between 8 and 15 November) is still somewhat different from the WACCM3 predictions, both observations and model prediction show relatively slow $\mathrm{HNO}_{3}$ changes over this week period (8-15 November).

\subsection{2 $\quad \mathrm{N}_{2} \mathrm{O}_{5}$ change}

Envisat MIPAS V3O_N ${ }_{2} \mathrm{O}_{5}-9$ measurements and WACCM3 computations of $\mathrm{N}_{2} \mathrm{O}_{5}$ are presented for the polar Northern Hemisphere $\left(70-90^{\circ} \mathrm{N}\right)$ in Fig. 10. The temporal change in Envisat MIPAS $\mathrm{N}_{2} \mathrm{O}_{5}$ during the nighttime in the polar Northern Hemisphere $\left(70-90^{\circ} \mathrm{N}\right)$, shown in Fig. 10 (top), is fairly similar to that given in Fig. 5 of López-Puertas et
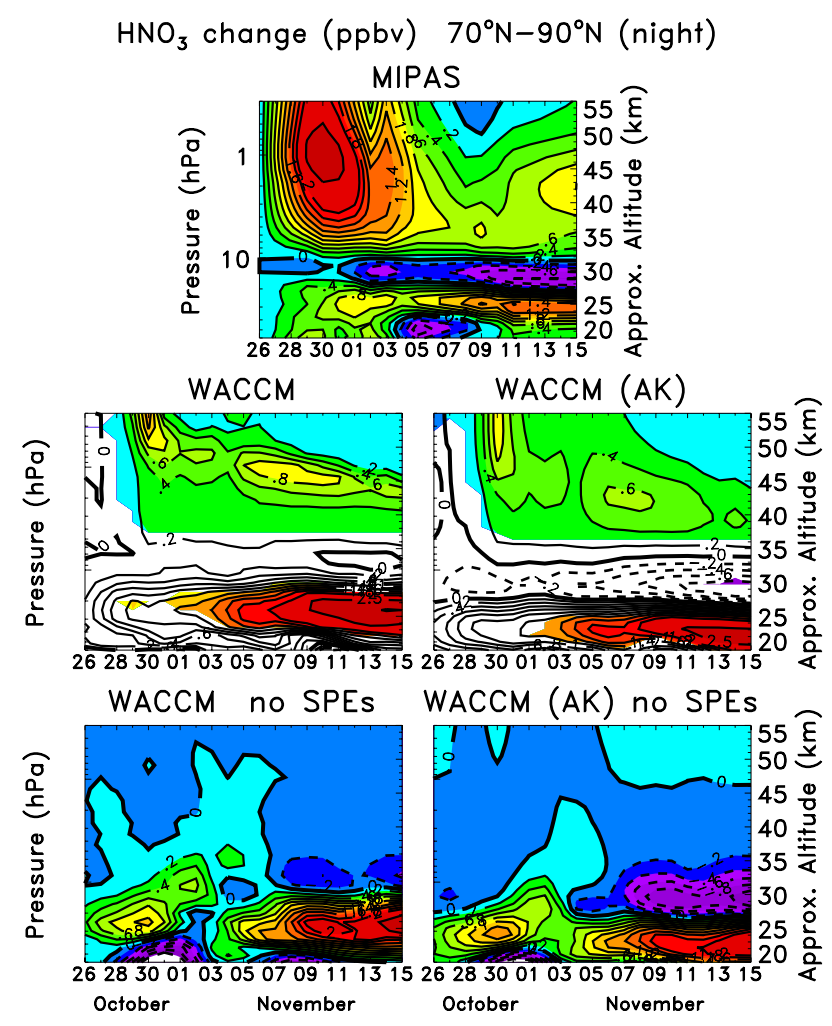

Fig. 9. Top plot is similar to Fig. 2a of López-Puertas et al. (2005b) but with the reprocessed version $\mathrm{V}_{3} \mathrm{O}_{-} \mathrm{HNO}_{3}-9$ data and shows the temporal evolution of MIPAS $\mathrm{HNO}_{3}$ abundance changes relative to 26 October for nighttime in the polar Northern Hemisphere (70$90^{\circ} \mathrm{N}$ ). Middle plots are derived from WACCM3 simulation 4(a), which includes SPEs, and indicate $\mathrm{HNO}_{3}$ changes relative to 25 October. The colored areas in the middle plots demonstrate the $2 \sigma$ statistically significant regions. Bottom plots are derived from WACCM3 simulation 4(w), which does not include SPEs, and indicates $\mathrm{HNO}_{3}$ seasonal changes relative to 25 October. Middle and bottom plots indicate usual sampling of the model [WACCM] and MIPAS averaging kernel applied to the WACCM results [WACCM $(\mathrm{AK})]$. Contour levels plotted are $-0.6,-0.4,-0.2,0.0,0.2,0.4,0.6$, $0.8,1.0,1.2,1.4,1.6,1.8,2.0,2.5$, and $3.0 \mathrm{ppbv}$.

al. (2005b) even though the reprocessed level-1b data and revised retrieval control parameters were used.

The usual sampling of model results from simulation 4(a) (see Fig. 10, middle left) show that $\mathrm{N}_{2} \mathrm{O}_{5}$ modeled enhancements peaked at about $45 \mathrm{~km}$ near the last day plotted (14 November), about $5 \mathrm{~km}$ higher than the MIPAS peak. Also, WACCM3 predicted $\mathrm{N}_{2} \mathrm{O}_{5}$ increases of 5-6 ppbv (primarily driven by the SPEs) in Fig. 10 (middle left) were significantly larger than the MIPAS measured increases of about 1 ppbv. The sampling of simulation 4(a) results with the MIPAS AK moves the peak of the $\mathrm{N}_{2} \mathrm{O}_{5}$ increases to about $40 \mathrm{~km}$, in better agreement with MIPAS. However, the predicted increases are still significantly higher than MIPAS with peak levels at about 4-5 ppbv. The colored areas in Fig. 10 (middle plots) 

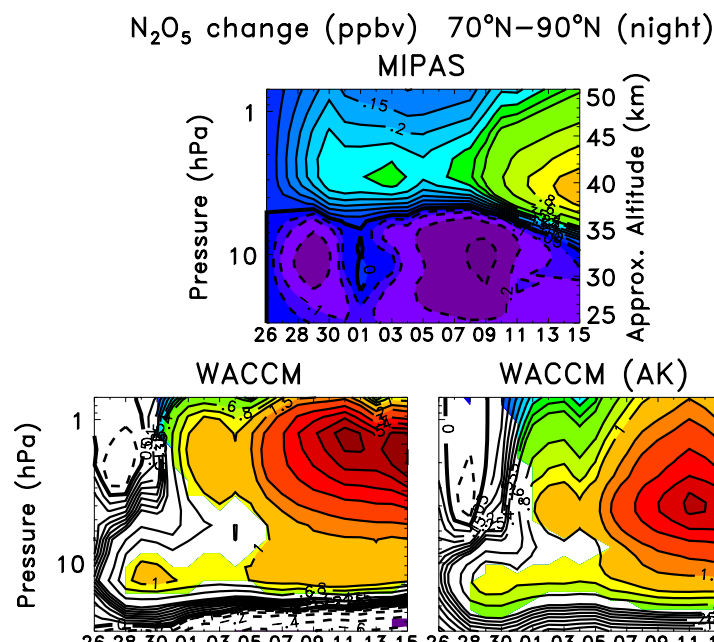

WACCM (AK)

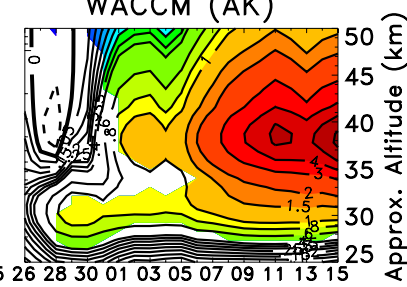

26283001030507091113152628300103050709111315 WACCM no SPES
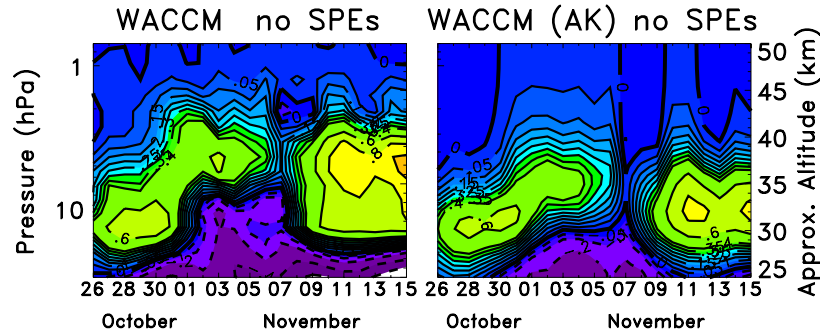

Fig. 10. Top plot is similar to Fig. 5 of López-Puertas et al. (2005b) but with the reprocessed version $\mathrm{V}_{3} \mathrm{O}_{-} \mathrm{N}_{2} \mathrm{O}_{5}-9$ data and shows the temporal evolution of MIPAS $\mathrm{N}_{2} \mathrm{O}_{5}$ abundance changes relative to 26 October for nighttime in the polar Northern Hemisphere (70$90^{\circ} \mathrm{N}$ ). Middle plots are derived from WACCM3 simulation 4(a) and indicate $\mathrm{N}_{2} \mathrm{O}_{5}$ changes relative to 25 October for night in $70-90^{\circ} \mathrm{N}$. The colored areas in the middle plots demonstrate the $2 \sigma$ statistically significant regions. Bottom plots are derived from WACCM3 simulation $4(\mathrm{w})$ and indicate $\mathrm{N}_{2} \mathrm{O}_{5}$ seasonal changes relative to 25 October. Middle and bottom plots indicate usual sampling of the model [WACCM] and MIPAS averaging kernel applied to the WACCM results [WACCM (AK)]. Contour levels plotted are $-0.6,-0.4,-0.2,-0.1,-0.05,0.0,0.05,0.1,0.15,0.2,0.25,0.3$, $0.35,0.4,0.6,0.8,1.0,1.5,2,3,4,5$, and $6 \mathrm{ppbv}$.

illustrate the regions where the perturbation is statistically significant at the $2 \sigma$ level.

WACCM3 predicted seasonal changes in $\mathrm{N}_{2} \mathrm{O}_{5}$ are shown in Fig. 10 (bottom plots) from a computation without SPEs [simulation $4(\mathrm{w})$ ]. These plots indicate the importance of the seasonal changes in forcing the $\mathrm{N}_{2} \mathrm{O}_{5}$ enhancement of 0.6 ppbv between 29 and $33 \mathrm{~km}$ from 26-31 October 2003 . The seasonal changes contribute somewhat to the $\mathrm{N}_{2} \mathrm{O}_{5}$ increases in the mid- to upper stratosphere $(30-50 \mathrm{~km})$ in November 2003 for both the usual sampling and the MIPAS AK sampling of the model results.

The cause of the discrepancy between the model and measurements at these altitudes could be related to the speed at which $\mathrm{N}_{2} \mathrm{O}_{5}$ is produced via

$\mathrm{NO}_{2}+\mathrm{NO}_{3}+\mathrm{M} \rightarrow \mathrm{N}_{2} \mathrm{O}_{5}+\mathrm{M}$.

For example, if this reaction proceeds much slower than indicated in Sander et al. (2003), then the build-up of $\mathrm{N}_{2} \mathrm{O}_{5}$ will be reduced after a large solar event. Conversely, the thermal decomposition reaction

$\mathrm{N}_{2} \mathrm{O}_{5}+\mathrm{M} \rightarrow \mathrm{NO}_{2}+\mathrm{NO}_{3}+\mathrm{M}$

and/or the photodissociation of $\mathrm{N}_{2} \mathrm{O}_{5}$ may be proceeding more rapidly than indicated in Sander et al. (2003), preventing a larger build-up of $\mathrm{N}_{2} \mathrm{O}_{5}$ after a large solar event. At the present time, it is impossible to determine what reaction(s) need to be corrected in WACCM3 to simulate better agreement with MIPAS. Also, the production of $\mathrm{N}_{2} \mathrm{O}_{5}$ is very sensitive to the temperature and dynamics. Differences between the predicted/real temperatures and/or differences in the dynamics (downward transport of earlier-produced $\mathrm{NO}_{2}$ ) might explain some of these differences.

\subsection{3 $\mathrm{ClONO}_{2}$ change}

We show Envisat MIPAS V3O_ClONO ${ }_{2} 9$ measurements and WACCM3 computations of $\mathrm{ClONO}_{2}$ in Fig. 11 for the polar Northern Hemisphere $\left(70-90^{\circ} \mathrm{N}\right)$. The MIPAS observations showed $\mathrm{ClONO}_{2}$ maximum enhancements at 35$40 \mathrm{~km}$ of $0.3-0.4 \mathrm{ppbv}$ starting right after the largest proton fluxes on 29-30 October (Fig. 11, top). The usual representation of model results from simulation 4(a) (see Fig. 11, middle left) show predicted $\mathrm{ClONO}_{2}$ increases at approximately the same amounts, however, the peak production was at a higher altitude $(40-45 \mathrm{~km})$ and several days later than measured.

The sampling of simulation 4(a) results with the MIPAS AK moves the peak of the $\mathrm{ClONO}_{2}$ increases to about $40 \mathrm{~km}$, in better agreement with MIPAS. However, the predicted peak increases are reduced substantially to about $0.2 \mathrm{ppbv}$, about a factor of two less than observed. The colored areas in Fig. 11 (middle plots) illustrate the regions where the perturbation is statistically significant at the $2 \sigma$ level.

The SPE-produced $\mathrm{NO}_{\mathrm{x}}$ leads to enhanced $\mathrm{ClONO}_{2}$ production via

$$
\mathrm{ClO}+\mathrm{NO}_{2}+\mathrm{M} \rightarrow \mathrm{ClONO}_{2}+\mathrm{M} \text {. }
$$

The cause of the discrepancy between the model and measurements at these altitudes could be related to the speed of this reaction. If this reaction proceeds much faster than indicated in Sander et al. (2003), then the build-up of $\mathrm{ClONO}_{2}$ will be enhanced to larger amounts more quickly after a large solar event. However, any changes in the rate for this reaction will also impact the $\mathrm{ClO}$ amounts (discussed below) and need to be considered carefully. Predicted seasonal changes (Fig. 11, bottom) mostly indicated increases over the time period although they appear to be primarily important below $35 \mathrm{~km}$. 


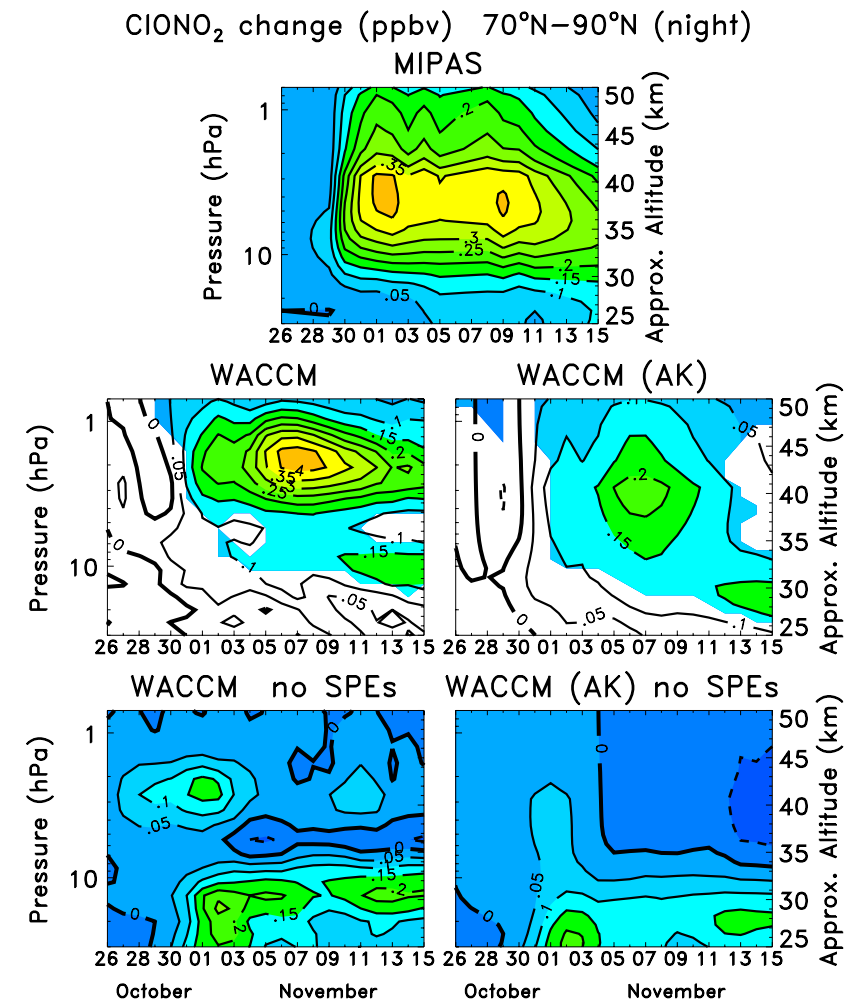

Fig. 11. Top plot is similar to Fig. 1 (bottom) of von Clarmann et al. (2005) and Fig. 8 of López-Puertas et al. (2005b) but with the reprocessed version $\mathrm{V} 3 \mathrm{O}_{-} \mathrm{ClONO}_{2}-9$ data and shows the temporal evolution of MIPAS $\mathrm{ClONO}_{2}$ abundance changes relative to 26 October for nighttime in the polar Northern Hemisphere (70$90^{\circ} \mathrm{N}$ ). Middle plots are derived from WACCM3 simulation 4(a) and indicate $\mathrm{ClONO}_{2}$ seasonal changes relative to 25 October. The colored areas in the middle plot demonstrate the $2 \sigma$ statistically significant regions. Bottom plots are derived from WACCM3 simulation $4(w)$ indicates $\mathrm{ClONO}_{2}$ seasonal changes relative to 25 October. Middle and bottom plots indicate usual sampling of the model [WACCM] and MIPAS averaging kernel applied to the WACCM results [WACCM (AK)]. Contour levels plotted are $-0.05,0.0,0.05$, $0.1,0.15,0.2,0.25,0.3,0.35$, and 0.4 ppbv.

\subsection{4 $\mathrm{HOCl}$ change}

Envisat MIPAS V2_HOCl_1 measurements and WACCM3 computations of $\mathrm{HOCl}$ simulation 4(a) are presented for the polar Northern Hemisphere $\left(70-90^{\circ} \mathrm{N}\right)$ in the top and bottom of Fig. 12, respectively. The measurements show significant $\mathrm{HOCl}$ enhancements in the altitude range $30-55 \mathrm{~km}$. The mechanism for increasing $\mathrm{HOCl}$ as a result of the SPEs involves enhancing the $\mathrm{HO}_{\mathrm{x}}$ constituents, which then speed up the following gas-phase three reaction sequence:

$$
\begin{aligned}
& \mathrm{OH}+\mathrm{HCl} \rightarrow \mathrm{H}_{2} \mathrm{O}+\mathrm{Cl} \\
& \mathrm{Cl}+\mathrm{O}_{3} \rightarrow \mathrm{ClO}+\mathrm{O}_{2} \\
& \mathrm{ClO}+\mathrm{HO}_{2} \rightarrow \mathrm{HOCl}+\mathrm{O}_{2} .
\end{aligned}
$$

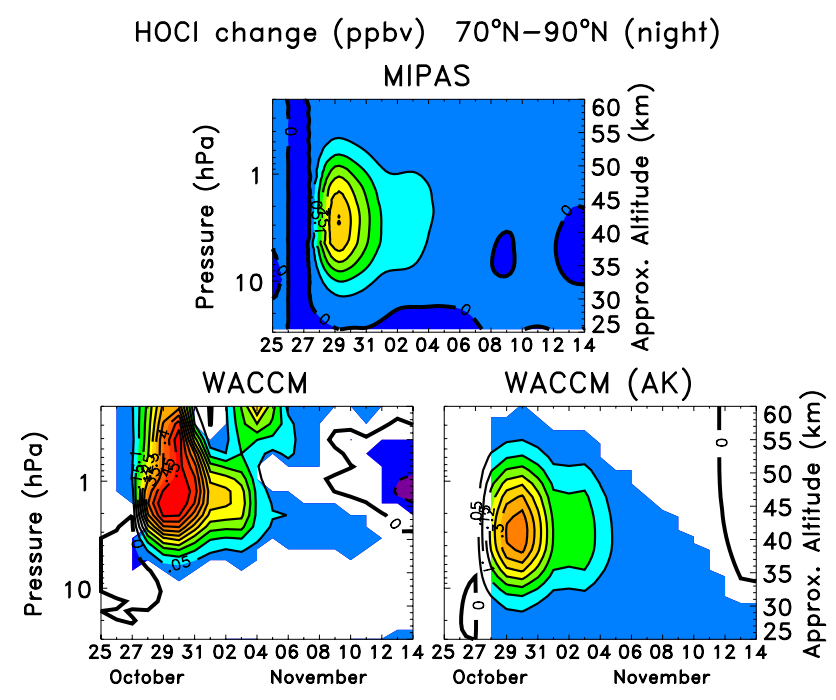

Fig. 12. Top plot is adapted from Fig. 1 (middle) of von Clarmann et al. (2005) and shows the temporal evolution of MIPAS V2_HOCl_1 measurements of $\mathrm{HOCl}$ changes relative to 26 October for nighttime in the polar Northern Hemisphere $\left(70-90^{\circ} \mathrm{N}\right)$. Bottom plot is derived from WACCM3 simulation 4(a) and indicates $\mathrm{HOCl}$ changes relative to 25 October. The colored areas in the bottom plots demonstrate the $2 \sigma$ statistically significant regions. Bottom plots indicate usual sampling of the model [WACCM] and MIPAS averaging kernel applied to the WACCM results [WACCM (AK)]. Contour levels plotted range from -0.05 to $0.5 \mathrm{ppbv}$ with an interval of 0.05 ..

The usual representation of model results from simulation 4(a) (see Fig. 12, bottom left) show WACCM3 predicted $\mathrm{HOCl}$ increases from $35 \mathrm{~km}$ up to $60 \mathrm{~km}$ and above. The modeled peak enhancement is about $0.2-0.25$ ppbv larger than measured. WACCM3 results also show a secondary $\mathrm{HOCl}$ peak on 4 November due to a smaller SPE in this period (Fig. 1).

The application of the MIPAS averaging kernels to the simulation 4(a) results moves the peak of the $\mathrm{HOCl}$ increases to the altitude range $30-55 \mathrm{~km}$ and totally eliminates the secondary $\mathrm{HOCl}$ peak, in better agreement with MIPAS. The predicted peak increases are reduced substantially and now are only about $0.1 \mathrm{ppbv}$ larger than observed. The colored areas in Fig. 12 (bottom plots) illustrate the regions where the perturbation is statistically significant at the $2 \sigma$ level.

We also investigated model predictions in the WACCM3 computation without SPEs [simulation 4(w), not shown] and found very small seasonal changes over this period, implying that practically all of the measured and modeled $\mathrm{HOCl}$ changes were due to the SPEs.

\subsubsection{ClO change}

$\mathrm{ClO}$ is closely coupled to $\mathrm{HOCl}$ and $\mathrm{ClONO}_{2}$. We show Envisat MIPAS V3O_ClO_11 measurements and WACCM3 computations of $\mathrm{ClO}$ in Fig. 13 for the polar Northern 


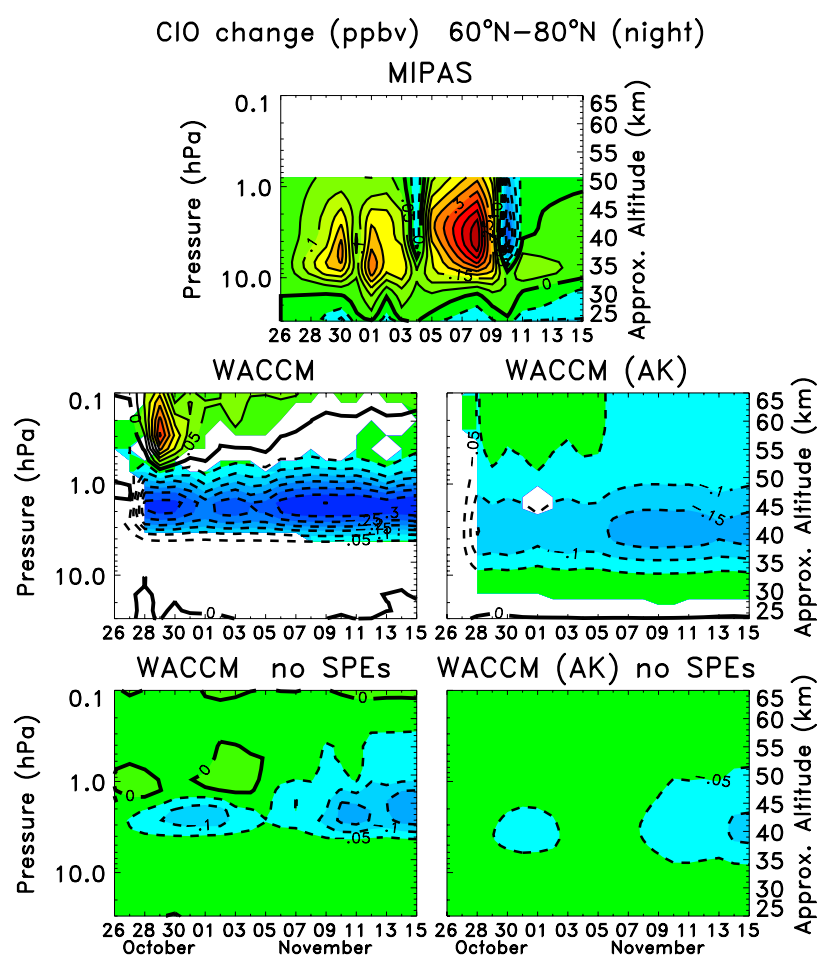

Fig. 13. Top plot is similar to Fig. 1 (top) of von Clarmann et al. (2005) and shows the temporal evolution of MIPAS V3O_ClO_11 measurement of $\mathrm{ClO}$ changes relative to 26 October for nighttime in the polar Northern Hemisphere $\left(60-80^{\circ} \mathrm{N}\right)$. Middle plots are derived from WACCM3 simulation 4(a) and indicate $\mathrm{ClO}$ changes relative to 25 October. The colored areas in the middle plot demonstrate the $2 \sigma$ statistically significant regions. Bottom plots are derived from WACCM3 simulation $4(\mathrm{w})$ indicate $\mathrm{ClO}$ seasonal changes relative to 25 October. Middle and bottom plots indicate usual sampling of the model [WACCM] and MIPAS averaging kernel applied to the WACCM results [WACCM (AK)]. Contour levels plotted range from -0.35 up to $0.45 \mathrm{ppbv}$ with an interval of 0.05 .

Hemisphere $\left(60-80^{\circ} \mathrm{N}\right)$. MIPAS provides better $\mathrm{ClO}$ measurements in this latitude band than that used for the other constituents in this section (i.e., $70-90^{\circ} \mathrm{N}$ ). Generally, the MIPAS observations show $\mathrm{ClO}$ enhancements in the 30 $50 \mathrm{~km}$ altitude range, peaking over $0.2 \mathrm{ppbv}$ on three separate days ( 30 Oct, 1 Nov, and 8 Nov), although there are two days ( 4 and 10 Nov) when decreases are measured. The usual representation of model results from simulation 4(a) (see Fig. 13, middle left) show predicted $\mathrm{ClO}$ increases only above $55 \mathrm{~km}$ and then only for about 3 days (28-31 Oct). Between 40 and $55 \mathrm{~km}$, the WACCM $3 \mathrm{ClO}$ shows a decrease throughout the time period with peak reductions over 0.3 ppbv.

The application of the MIPAS averaging kernels to the simulation 4(a) results moves the decreases in $\mathrm{ClO}$ to lower altitudes and diminishes the peak $\mathrm{ClO}$ reductions to $\sim 0.15$ ppbv. The colored areas in Fig. 13 (middle plots) il- lustrate the regions where the perturbation is statistically significant at the $2 \sigma$ level. Predicted seasonal changes (Fig. 13, bottom) mostly indicated decreases over the time period that are about $1 / 3$ to $1 / 2$ of the computed changes occurring at this time of year.

The production of $\mathrm{ClO}$ during SPEs was discussed in von Clarmann et al. (2005). SPE-produced $\mathrm{OH}$ can release reactive chlorine $(\mathrm{Cl})$ from the reservoir $\mathrm{HCl}$ $\left(\mathrm{OH}+\mathrm{HCl} \rightarrow \mathrm{H}_{2} \mathrm{O}+\mathrm{Cl}\right)$ and lead to the creation of $\mathrm{ClO}$ $\left(\mathrm{Cl}+\mathrm{O}_{3} \rightarrow \mathrm{ClO}+\mathrm{O}_{2}\right)$. Loss of $\mathrm{ClO}$ during SPEs is also possible through the SPE-produced $\mathrm{HO}_{2}\left(\mathrm{HO}_{\mathrm{x}}\right)$ and $\mathrm{NO}_{2}\left(\mathrm{NO}_{\mathrm{x}}\right)$ creating $\mathrm{HOCl}$ and $\mathrm{ClONO}_{2}$ via the reactions $\mathrm{ClO}+\mathrm{HO}_{2} \rightarrow$ $\mathrm{HOCl}+\mathrm{O}_{2}$ and $\mathrm{ClO}+\mathrm{NO}_{2}+\mathrm{M} \rightarrow \mathrm{ClONO}_{2}+\mathrm{M}$.

The reasons behind the significant differences between MIPAS and WACCM3 ClO are presently not known. A study with a simpler model, which would allow easier addition or subtraction of included reactions and/or modifications in reaction rates, would be helpful in elucidating the major causes of these discrepancies.

\section{SPE-induced medium-term (months) changes in com- position}

Very large SPEs produced $\mathrm{NO}_{\mathrm{x}}$ in the polar mesosphere and upper stratosphere (Zadorozhny et al., 1992; Jackman et al., 2001, 2005; López-Puertas et al., 2005b). These $\mathrm{NO}_{\mathrm{x}}$ perturbations were significantly reduced in the sunlit hemisphere through the two step process $[\mathrm{NO}+\mathrm{h} \nu \rightarrow \mathrm{N}+\mathrm{O}$ followed by $\left.\mathrm{N}+\mathrm{NO} \rightarrow \mathrm{N}_{2}+\mathrm{O}\right]$. However, the SPE-caused $\mathrm{NO}_{x}$ enhancements in the darker hemisphere had a very long lifetime ( $\sim$ months $)$ and ended up being transported to the middle and lower stratosphere. This increased $\mathrm{NO}_{\mathrm{x}}$ had associated ozone decreases over its lifetime. We will discuss this process following the very large SPEs of July 2000 and October 1989 and show measurements and model simulations for 2 5 months past these SPEs. We will also show evidence of longer lasting ( $\sim$ two months) SPE-caused ozone depletion following the August 1972 SPEs, likely caused by the SPEproduced $\mathrm{NO}_{\mathrm{x}}$ enhancements.

\subsection{July 2000 Solar Proton Event}

The July 2000 SPE produced large amounts of $\mathrm{NO}_{\mathrm{x}}$, which was observed by HALOE and simulated in a 2-D model (Jackman et al., 2001). We computed an ensemble average of the two groups of simulations $3(a, b, c, d)$ and $3(w$, $\mathrm{x}, \mathrm{y}, \mathrm{z})$ and differenced the two to derive the results shown in Fig. 14. Note the near anti-correlation of $\mathrm{NO}_{\mathrm{x}}$ (Fig. 14, left) and ozone (Fig. 14, right) over most of this period. The $\mathrm{HO}_{\mathrm{x}}$ constituents (not shown) produced during the SPE on days 196-198 (14-16 July) are responsible for the short-lived large ozone decreases $(>40 \%)$. The SPE-caused $\mathrm{NO}_{\mathrm{x}}$ enhancement then drives the ozone depletion after this period. This is consistent with the downwelling associated with the 

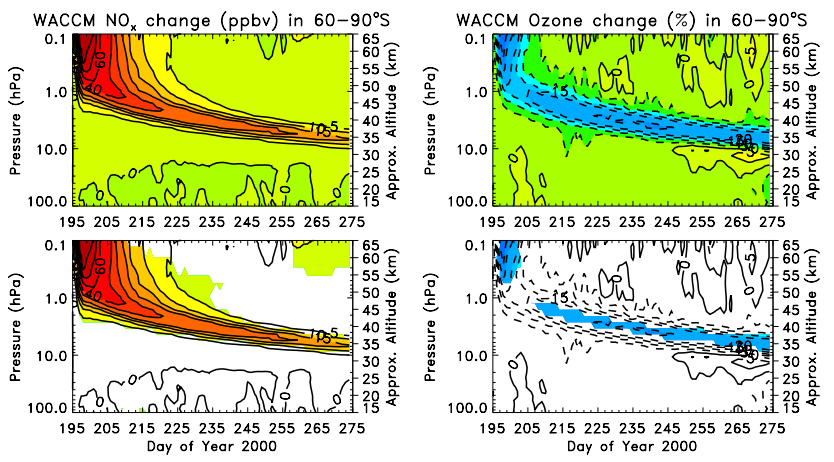

Fig. 14. Derived from WACCM 3 output showing the difference of the ensemble average of simulations $3(a, b, c, d)$ compared to the ensemble average of simulations $3(\mathrm{w}, \mathrm{x}, \mathrm{y}, \mathrm{z})$ for the latitude band $60-90^{\circ} \mathrm{S}$ from day 195 (13 July) through day 275 (1 October) for year 2000. Top left plot indicates $\mathrm{NO}_{\mathrm{x}}$ change with contour levels of $0,5,10,15,20,30,40,60,80$, and 100 ppbv. Top right plot indicates ozone change with contour levels of $-40,-30,-20$, $-15,-10,-5,0$, and $5 \%$. Bottom plots are the top plots repeated with the colored areas indicating the regions which are statistically significant at the $2 \sigma$ level for $\mathrm{NO}_{\mathrm{x}}$ and ozone.

residual circulation over the SH polar regions during July. By about day 255 (11 September), a $\mathrm{NO}_{\mathrm{x}}$ increase of $>5 \mathrm{ppbv}$ appears to cause an ozone loss of $>10 \%$. The rate of descent of the $\mathrm{NO}_{\mathrm{x}}$ and ozone perturbation is about $140 \mathrm{~m} /$ day $(\sim 0.16 \mathrm{~cm} / \mathrm{s})$ over this period consistent with the residual circulation velocities during this time. Near the end of the plotted period (day 274), predicted $\mathrm{NO}_{\mathrm{x}}$ enhancements greater than about $4 \mathrm{ppbv}$ and ozone decreases greater than about $20 \%$ are statistically significant at $2 \sigma$, which are indicated by the colored areas in the bottom plots in Fig. 14.

Is there any evidence of SPE-caused $\mathrm{NO}_{\mathrm{x}}$ enhancements lasting at least six weeks after the event period, as simulated by WACCM3? Yes: Randall et al. (2001) showed evidence from HALOE observations of large $\mathrm{NO}_{\mathrm{x}}\left(\mathrm{NO}+\mathrm{NO}_{2}\right)$ enhancements two months after this July 2000 SPE in the Southern Hemisphere. Ten years of HALOE observations are presented in Fig. 15 (left). Although there is evidence of interannual variability, the year 2000 shows enhancements of $\mathrm{NO}_{\mathrm{x}}$ by about a factor of $2-3$ beyond the normal range near $1000 \mathrm{~K}(\sim 33 \mathrm{~km})$.

We have sampled the WACCM3 output of simulation 1(a) in a similar manner and present the results in Fig. 15 (right). The WACCM3 results indicate somewhat larger interannual variability above about $32 \mathrm{~km}$, and less variability below this altitude. Both HALOE and WACCM3 show $\mathrm{NO}_{\mathrm{x}}$ enhancements in year 2000 greater than $10 \mathrm{ppbv}$ beyond the normal range. $\mathrm{NO}_{\mathrm{x}}$ changes greater than about $4 \mathrm{ppbv}$ are statistically significant at the $2 \sigma$ level throughout this altitude range at this time of year. Thus the July 2000 SPE likely led to these September $2000 \mathrm{NO}_{\mathrm{x}}$ increases.
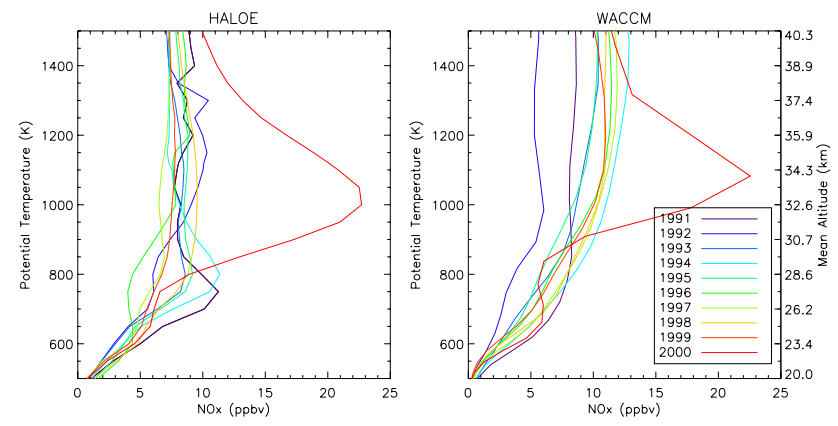

Fig. 15. Left plot is an adaptation of Fig. 5a of Randall et al. (2001) showing Southern Hemisphere $(\mathrm{SH})$ polar vortex HALOE $\mathrm{NO}_{\mathrm{x}}$ (ppbv) profiles in September/October for years 1991-2000. Right plot shows WACCM3 simulation 1(a) predicted SH polar vortex $\mathrm{NO}_{\mathrm{x}}$ (ppbv) profiles for the same periods.

The sharper peak in WACCM3 is likely related to the coarser altitude grid in the model. There are differences in the interannual variability in WACCM3 compared with HALOE near the top level shown $(1500 \mathrm{~K}, \sim 40 \mathrm{~km})$ in Fig. 15. The cause of these differences in the upper stratosphere between WACCM3 and HALOE may be related to A) a larger production in WACCM3 of lower thermospheric $\mathrm{NO}_{\mathrm{x}}$ via auroral electrons than exists in the atmosphere; $\mathrm{B}$ ) a larger downward transport in WACCM3 of $\mathrm{NO}_{\mathrm{x}}$ from the lower thermosphere to the stratosphere; $\mathrm{C}$ ) a combination of A) and B); or D) other differences between WACCM3 and the atmosphere. It is unclear what the differences in the lower stratosphere between WACCM3 and HALOE mean. A strong possibility is that there are different dynamics in the model and actual atmosphere. For instance, the local maxima near $700-800 \mathrm{~K}$ in the HALOE data likely result from downward transport of $\mathrm{NO}_{\mathrm{x}}$ produced earlier in the winter at higher altitudes by energetic particle precipitation (see Randall et al., 2007); WACCM3 might not be simulating this transport adequately. Recall that since the version of WACCM3 used here is not forced by analyzed winds, we do not expect the model dynamics to match the atmospheric dynamics in detail for any specific year.

\subsection{August 1972 Solar Proton Events}

The second largest SPE period in the past 45 years occurred 2-10 August 1972 (days 215-223). Although this SPE period occurred about 35 years ago, there were recorded measurements of its ozone impact (e.g. Heath et al., 1977; Reagan et al., 1981; McPeters et al., 1981; Jackman and McPeters, 1987; Jackman et al., 1990). We compare our WACCM3 predicted ozone changes to measured ozone changes from the backscattered ultraviolet (BUV) instrument on the Nimbus 4 satellite between about 32 and $53 \mathrm{~km}$ for 60 days in Fig. 16. The BUV changes (Fig. 16a) were derived by comparing 1972 to 1970 ozone data (Jackman et al., 


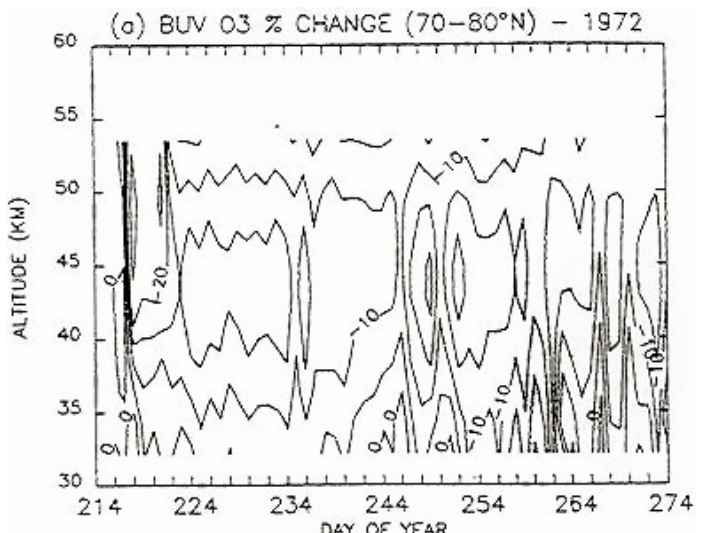

(b) WACCM $\mathrm{O}_{3}\left(\%\right.$ change) $70^{\circ} \mathrm{N}-80^{\circ} \mathrm{N}$

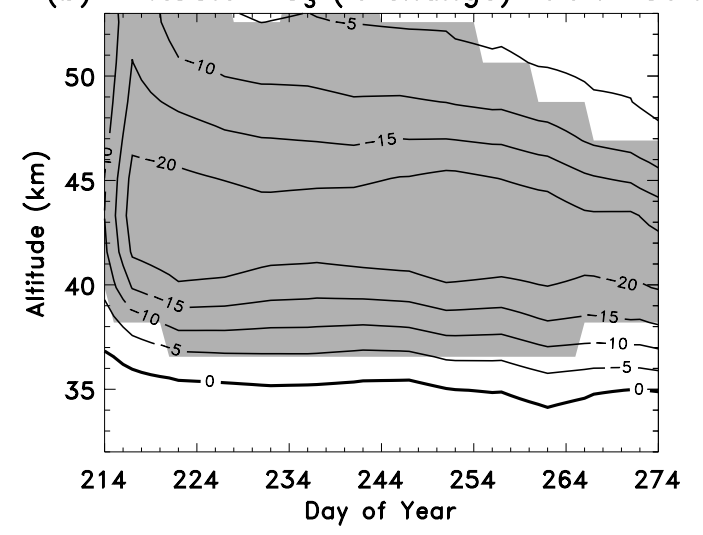

Fig. 16. Plot (a) is taken from Fig. 6 of Jackman et al. (1990) and shows the temporal evolution of measured ozone abundance changes in 1972 relative to 1970 by the backscattered ultraviolet (BUV) instrument aboard the Nimbus 4 satellite for the latitude band $70-80^{\circ} \mathrm{N}$. Plot (b) is derived from the WACCM3 ensemble average of simulations $1(\mathrm{a}, \mathrm{b}, \mathrm{c}, \mathrm{d})$ and indicates ozone changes in 1972 relative to 1970 in the same latitude bands. The shaded area in plot (b) demonstrates the $2 \sigma$ statistically significant region. Contour levels plotted are $-30,-20,-15,-10,-5$, and $0 \%$.

1990) in latitude band $70-80^{\circ} \mathrm{N}$. The WACCM 3 computed ozone changes (Fig. 16b) were derived by averaging the ensemble of simulations $1(a, b, c, d)$ and comparing 1972 to 1970 for the same latitude band. The shaded area in Fig. 16b illustrate the regions where the perturbation is statistically significant at the $2 \sigma$ level.

There is reasonable agreement between the model and measurement with both showing significant ozone depletion ( $>10 \%)$ in the upper stratosphere $(\sim 40-50 \mathrm{~km})$ over most of the 60 -day time period in the $70-80^{\circ} \mathrm{N}$ latitude band. Both model and measurement show modest ozone depletion (5$10 \%$ ) in the altitude region $40-45 \mathrm{~km}$ over most of the period in the $50-60^{\circ} \mathrm{N}$ latitude band (not shown). Also, the measurements indicate a larger ozone depletion in the 33$40 \mathrm{~km}$ region for both latitude bands than simulated by the model. As explained in Jackman et al. (2000), only proton
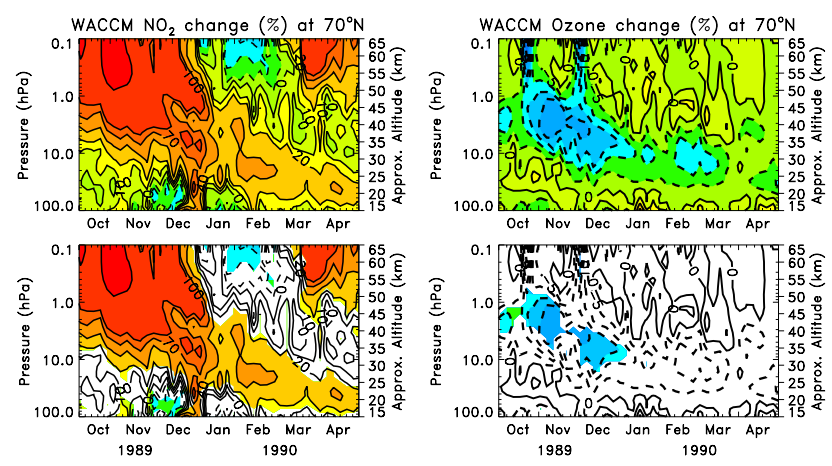

Fig. 17. Temporal evolution of WACCM3-computed percentage ozone change in 1989 for the ensemble average of simulations 2(a, b, c, d) average compared to the ensemble average of simulations $2(\mathrm{w}, \mathrm{x}, \mathrm{y}, \mathrm{z})$ at $70^{\circ} \mathrm{N}$ for $\mathrm{NO}_{2}$ (top left) and Ozone (top right). Contour levels for $\mathrm{NO}_{2}$ are $-40,-20,-10,0,10,20,40,70,100$, and $1000 \%$. Contour levels for Ozone are $-20,-15,-10,-5,0,5$, 10 , and $15 \%$. Bottom plots are the top plots repeated with the colored areas indicating the regions which are statistically significant at the $2 \sigma$ level for $\mathrm{NO}_{2}$ and ozone.

fluxes with energies less than $100 \mathrm{MeV}$ were included for these SPEs. The August 1972 events probably had protons with energies greater than $100 \mathrm{MeV}$, which affect altitudes below $35 \mathrm{~km}$. These high-energy protons, however, could not be reliably included into our computations.

\subsection{October 1989 Solar Proton Events}

The largest SPE period in the past 45 years occurred 19-27 October (Days 292-300), 1989. The $\mathrm{NO}_{\mathrm{y}}$ produced during this period was nearly a factor of two larger than the second largest SPE period (see Table 1). Both rocket measurements (NO; Zadorozhny et al., 1992) and satellite measurements (ozone and $\mathrm{NO}_{2}$; Jackman et al., 1993, 1995) showed atmospheric changes as a result of these extremely intense SPEs.

We computed an ensemble average of the two groups of simulations $2(\mathrm{a}, \mathrm{b}, \mathrm{c}, \mathrm{d})$ and $2(\mathrm{w}, \mathrm{x}, \mathrm{y}, \mathrm{z})$ and differenced the two to derive the percentage change shown for $\mathrm{NO}_{2}$ (Fig. 17, left) and ozone (Fig. 17, right) at $70^{\circ} \mathrm{N}$. Very large upper stratospheric enhancements of $\mathrm{NO}_{2}$ greater than $100 \%$ from late October to early December drive ozone decreases greater than $20 \%$. The substantial ozone depletion $(>10 \%)$ between 2 and $4 \mathrm{hPa}$ before the 19-27 October SPE period was mainly caused by prior large SPE periods in 13-26 August 1989 and 29 September-3 October 1989 (see Table 1), which produced sufficient $\mathrm{NO}_{\mathrm{x}}$ to cause a longer-lived ozone loss. The $\mathrm{NO}_{2}$ enhancement in March 1990 was caused by a medium sized SPE (Fig. 17, left). No associated short-term ozone loss by $\mathrm{HO}_{\mathrm{x}}$ constituents is seen in Fig. 17 (right) because WACCM3 output was only every five days for these simulations and the SPE's influence on mesospheric and upper stratospheric ozone on 19-20 March 1990 was missed. 
Statistically significant $2 \sigma$ changes are shown in the colored areas in the bottom plots of Fig. 17. The enhanced $\mathrm{NO}_{2}$ signal from the Oct. 1989 SPEs is transported downwards and slowly diluted over the seven months (Oct 1989-April 1990), however, increases greater than about $20 \%$ remain at the end of the period. The reduced ozone signal is also transported downwards and slowly diluted as well. Some of the $\mathrm{NO}_{2}$ signal is statistically significant to $2 \sigma$ over the entire period, whereas the ozone signal is not statistically significant after the end of 1989.

We computed the ozone change in the latitude band 60 $80^{\circ}$ from the WACCM3 simulations $2(\mathrm{a}, \mathrm{b}, \mathrm{c}, \mathrm{d})$ at $4 \mathrm{hPa}$ (December 1989 contrasted with the December 1990 and December 1991 average) to be: 1) $-6 \%$ for the $\mathrm{SH}$; and 2) $-18 \%$ for the NH. These model results can be compared to the NOAA $11 \mathrm{SBUV} / 2$ measurements taken from Jackman et al. (1995, Table 1) of: 1) $-1 \%$ for the $\mathrm{SH}$; and 2) $-12 \%$ for the $\mathrm{NH}$. Although there are quantitative differences between WACCM3 and SBUV/2 measurements, the prediction of a substantially larger ozone depletion in the NH than the SH in December 1989 is similar to the measurements. These WACCM3 results complement the threedimensional chemistry-transport-model results given in Jackman et al. (1995). The interhemispheric difference in the ozone loss results is caused by the difference in seasons in the $\mathrm{SH}$ and $\mathrm{NH}$. The $\mathrm{SH}$ has a high solar zenith angle, promoting destruction of $\mathrm{NO}_{\mathrm{x}}$ through a two-step process [NO+h $\nu \rightarrow \mathrm{N}+\mathrm{O}$ followed by $\mathrm{N}+\mathrm{NO} \rightarrow \mathrm{N}_{2}+\mathrm{O}$ ] Thus, less $\mathrm{NO}_{\mathrm{x}}$ is available to deplete ozone in the $\mathrm{SH}$ compared with the NH.

SAGE II ozone and $\mathrm{NO}_{2}$ measurements over five months after this extreme proton flux period have been reported before in a comparison with 3D model predictions (Jackman et al., 1995). SAGE II observations and WACCM3 simulation results are presented for $\mathrm{NO}_{2}$ (Fig. 18, top) and ozone (Fig. 18, bottom) for 31 March 1990. The SAGE II observations were derived by computing the percentage difference on 31 March 1990 compared with 31 March 1987 and are represented by the solid line with asterisks. WACCM3 (case 1) results, represented by the dotted line, were derived using the ensemble mean of simulations $1(\mathrm{a}, \mathrm{b}, \mathrm{c}, \mathrm{d})$ and computing the percentage difference on 31 March 1990 compared with 31 March 1987. WACCM3 (case 2) results, represented by the dashed line, was derived from the ensemble average of simulations 2(a, b, c, d) differenced with the ensemble average of simulations 2(w, x, y, z) for 31 March 1990.

SAGE II measurements and WACCM3 predictions show large enhancements in $\mathrm{NO}_{2}$ on 31 March 1990 (Fig. 18, top): $\sim 68 \%$ at $21 \mathrm{~km}$ for SAGE II; $\sim 105 \%$ at $22 \mathrm{~km}$ for WACCM3 (case 1); and $\sim 34 \%$ at $22 \mathrm{~km}$ for WACCM3 (case 2). These results point to a substantial downward transport of $\mathrm{NO}_{\mathrm{y}}$ (in general) and $\mathrm{NO}_{2}$ (in particular) after the SPEs (also, see Fig. 17, left). Although there are differences between the model simulations and measurements in the absolute amount of enhanced $\mathrm{NO}_{2}$ on 31 March 1990 as a result of the Oc-
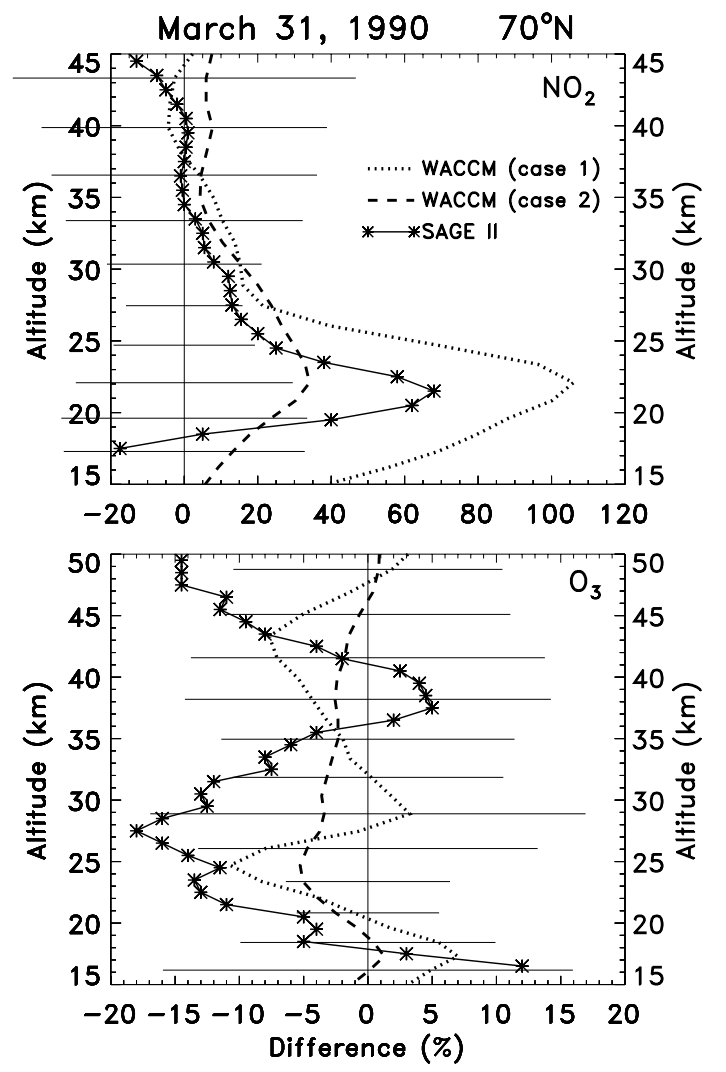

Fig. 18. SAGE II measurements (solid line) and WACCM3 predictions (dashed and dotted lines) for $70^{\circ} \mathrm{N}$ zonal mean percentage change for 31 March 1990 for constituents (top) $\mathrm{NO}_{2}$ and (bottom) $\mathrm{O}_{3}$. SAGE II results were derived by computing the percentage difference on 31 March 1990 compared with 31 March 1987. WACCM3 (case 1) was derived using the ensemble mean of simulations $1(\mathrm{a}, \mathrm{b}, \mathrm{c}, \mathrm{d})$ and computing the percentage difference on 31 March 1990 compared with 31 March 1987. WACCM3 (case 2) was derived from the ensemble average of simulations $2(a, b, c, d)$ differenced with the ensemble average of simulations $2(w, x, y, z)$ for 31 March 1990. The horizontal lines in the plots demonstrate the $2 \sigma$ values for $\mathrm{NO}_{2}$ and ozone.

tober 1989 SPEs, it is clear that these SPEs have led to an increase in $\mathrm{NO}_{2}$. The horizontal lines in Fig. 18 indicate statistical significance at the $2 \sigma$ level. Most of the WACCM3 $\mathrm{NO}_{2}$ changes below $30 \mathrm{~km}$ are statistically significant.

Some of the differences between WACCM3 and SAGE II $\mathrm{NO}_{2}$ changes may well be related to interannual variability (see discussion in Jackman et al., 1995). Randall et al. (2006) also showed that varying meteorology plays a substantial role in determining the distribution of $\mathrm{NO}_{\mathrm{x}}$ in the $\mathrm{NH}$ middle atmosphere several months after energetic particle precipitation. Differences in medium-term changes in composition between the model and measurements are thus expected for these WACCM3 runs in which the model dynamics do not correspond to any particular year. 
The measured and modeled decreases in ozone are in qualitative agreement near $25 \mathrm{~km}$ (Fig. 18, bottom): $\sim 11 \%$ for SAGE II; $\sim 10 \%$ for WACCM3 (case 1); and $\sim 5 \%$ for WACCM3 (case 2). The measured and modeled ozone changes above $25 \mathrm{~km}$ indicate substantial variations with altitude. The polar regions have large interannual dynamical variations in both measurements and model simulations; thus, it is difficult to predict precisely the ozone impact over five months after this extremely large SPE period. As discussed above for Fig. 17, none of the modeled ozone changes for 31 March 1990 are statistically significant at the $2 \sigma$ level.

We note finally that the $\mathrm{NO}_{2}$ enhancements primarily cause stratospheric ozone loss through the catalytic cycle given in section 1. However, the increased $\mathrm{NO}_{2}$ also can lead to $\mathrm{ClONO}_{2}$ and $\mathrm{BrONO}_{2}$ increases [e.g., $\left.\mathrm{NO}_{2}+\mathrm{ClO}+\mathrm{M} \rightarrow \mathrm{ClONO}_{2}+\mathrm{M}\right]$. These changes may also then lead to ozone increases in the lower stratosphere through interference with the halogen-driven ozone loss processes (Jackman et al., 2000). The long-term changes caused by the $\mathrm{NO}_{\mathrm{y}}$ family enhancements as a result of SPEs will be addressed in a future study.

\section{Conclusions}

The WACCM3 has been used to study the short-term (days) and medium-term (months) constituent changes caused by SPEs over the 1963-2005 time period. The most pronounced atmospheric effects were caused by the very largest SPEs in this period and are concentrated in the polar regions. The four largest SPEs in the past 45 years (August 1972; October 1989; July 2000; and October-November 2003) have satellite instrument observations of atmospheric changes with which to compare. Generally, there is reasonable agreement between the WACCM3 predictions and the observations, especially for SPE-caused $\mathrm{NO}_{\mathrm{x}}$ enhancements and ozone depletion. Polar mesospheric $\mathrm{NO}_{\mathrm{x}}\left(\mathrm{NO}+\mathrm{NO}_{2}\right)$ increased by over 50 ppbv and mesospheric ozone decreased by over $30 \%$ during these very large SPE periods.

There are, however, some disagreements between WACCM3 and satellite instrument observed enhancements of $\mathrm{HNO}_{3}, \mathrm{~N}_{2} \mathrm{O}_{5}, \mathrm{ClONO}_{2}$, and $\mathrm{ClO}$. Application of the MIPAS averaging kernel to the WACCM3 output has helped in the comparison. The MIPAS measured enhanced $\mathrm{HNO}_{3}$ is rather temporary (29-31 October 2003), extends over a larger altitude range, and is much larger than that predicted by WACCM3. Conversely, the MIPAS measured $\mathrm{N}_{2} \mathrm{O}_{5}$ enhancements are much smaller than predicted by WACCM3, but build up over a period of 10-14 days after the SPEs. The source of these measurement/model disagreements is unclear and may be related to the lack of certain photochemical reactions in WACCM3 or the speed of particular reaction rates included in WACCM3. The measured and predicted $\mathrm{ClONO}_{2}$ increases peak near the same altitude, however, MIPAS indicates maximum enhancements a few days earlier and about a factor of two larger than WACCM3. The WACCM3 simulated $\mathrm{ClO}$ is very different from the MIPAS observations with the model indicating a decrease and the measurements showing an increase. These differences are very puzzling and need to be studied with a simpler model. The fairly similar $\mathrm{HOCl}$ peak amounts and temporal variation in MIPAS and WACCM3 must also be considered.

SPE-caused medium-term (months) were also investigated. WACCM3 predicted polar upper stratospheric and lower mesospheric $\mathrm{NO}_{\mathrm{x}}$ increases of over $10 \mathrm{ppbv}$, which were transported during polar night down to the middle stratosphere in several weeks as a result of the July 2000 $\mathrm{SPE}$. This WACCM3 simulated $\mathrm{NO}_{\mathrm{x}}$ enhancement was compared with HALOE measured $\mathrm{NO}_{\mathrm{x}}$ in September 2000 and was found to be in reasonable agreement. Predicted $\mathrm{NO}_{2}$ enhancements in March 1990 resulting from the October 1989 SPEs were compared to SAGE II measurements and showed qualitative agreement. Interannual transport variations and differences between WACCM3 and the atmosphere also contribute to model/measurement discrepancies in time periods several months past the events.

A manuscript in preparation will discuss the WACCM3 simulated long-term (months to years) atmospheric effects of very large SPEs.

Acknowledgements. This work was supported by the NASA Living With a Star Targeted Research and Technology Program and the NASA Atmospheric Composition Modeling and Analysis Program. The IAA team was supported by the Spanish project ESP2004-01556 and EC FEDER funds. The IMK team was supported by the German Research Foundation (DFG) via the CAWSES priority program, project MANOXUVA, and by BMBF under contract $50 \mathrm{EE}$ 0512. WACCM3 results presented in this paper were generated using NASA's Columbia supercomputer housed at the NASA Ames Research Center.

Edited by: V. Fomichev

\section{References}

Armstrong, T. P., Brundardt, C., and Meyer, J. E.: Satellite observations of interplanetary and polar cap solar particle fluxes from 1963 to the present, in: Weather and Climate Response to Solar Variations, edited by: McCormac, B. M., Colorado Associated University Press, Boulder, 71-79, 1983.

Banks, P. M.: Joule heating in the high-latitude mesosphere, J. Geophys. Res., 84, 6709-6712, 1979.

Brasseur, G. and Solomon, S.: Aeronomy of the Middle Atmosphere, D. Reidel Publising Company, Dordrecht, Holland, p. 245, 1984.

Collins, W. D., Rasch, P. J., Boville, B. A., Hack, J. J., McCaa, J. R., Williamson, D. L., Kiehl, J. T., Briegleb, B., Bitz, C., Lin, S.-J., Zhang, M., and Dai, Y.: Description of the NCAR Community Atmosphere Model (CAM3), NCAR Technical Note, NCAR/TN-464+STR, 226 pp., 2004. 
Crutzen, P. J., Isaksen, I. S. A., and Reid, G. C.: Solar proton events: Stratospheric sources of nitric oxide, Science, 189, 457458, 1975.

Fabian, P., Pyle, J. A., and Wells, R. J.: The August 1972 solar proton event and the atmospheric ozone layer, Nature, 277, 458460, 1979.

Forkman, P., Eriksson, P., Winnberg, A., Garcia, R. R., and Kinnison, D.: Longest continuous ground-based measurements of mesospheric CO, Geophys. Res. Lett., 30, 1532, doi:10.1029/2003GL016931, 2003.

Frederick, J. E.: Solar corpuscular emission and neutral chemistry in the Earth's middle atmosphere, J. Geophys. Res., 81, 31793186, 1976.

Garcia, R. R., Marsh, D., Kinnison, D., Boville, B., and Sassi, F.: Simulation of secular trends in the middle atmosphere, J. Geophys. Res., 112, D09301, doi:10.1029/2006JD007485, 2007.

Heath, D. F., Krueger, A. J., and Crutzen, P. J.: Solar proton event: influence on stratospheric ozone, Science, 197, 886-889, 1977.

Jackman, C. H. and McPeters, R. D.: The response of ozone to solar proton events during solar cycle 21: A theoretical interpretation, J. Geophys. Res., 90, 7955-7966, 1985.

Jackman, C. H. and McPeters, R. D.: Solar proton events as tests for the fidelity of middle atmosphere models, Physica Scripta, T18, 309-316, 1987.

Jackman, C. H. and McPeters, R. D.: The Effect of Solar Proton Events on Ozone and Other Constituents, in: Solar Variability and its Effects on Climate, Geophys. Mon. 141, 305-319, 2004.

Jackman, C. H., Frederick, J. E., and Stolarski, R. S.: Production of odd nitrogen in the stratosphere and mesosphere: An intercomparison of source strengths, J. Geophys. Res., 85, 7495-7505, 1980.

Jackman, C. H., Douglass, A. R., Guthrie, P. D., and Stolarski, R. S.: The sensitivity of total ozone and ozone perturbation scenarios in a two-dimensional model due to dynamical inputs, J. Geophys. Res., 94, 9873-9887, 1989.

Jackman, C. H., Douglass, A. R., Rood, R. B., McPeters, R. D., and Meade, P. E.: Effect of solar proton events on the middle atmosphere during the past two solar cycles as computed using a two-dimensional model, J. Geophys. Res., 95, 7417-7428, 1990.

Jackman, C. H., Nielsen, J. E., Allen, D. J., Cerniglia, M. C., McPeters, R. D., Douglass, A. R., and Rood, R. B.: The effects of the October 1989 solar proton events on the stratosphere as computed using a three-dimensional model, Geophys. Res. Lett., 20, 459-462, 1993.

Jackman, C. H., Cerniglia, M. C., Nielsen, J. E., Allen, D. J., Zawodny, J. M., McPeters, R. D., Douglass, A. R., Rosenfield, J. E., and Rood, R. B.: Two-dimensional and three-dimensional model simulations, measurements, and interpretation of the influence of the October 1989 solar proton events on the middle atmosphere, J. Geophys. Res., 100, 11 641-11 660, 1995.

Jackman, C. H., Fleming, E. L., Chandra, S., Considine, D. B., and Rosenfield, J. E.: Past, present and future modeled ozone trends with comparisons to observed trends, J. Geophys. Res., 101, 28753-28 767, 1996.

Jackman, C. H., Fleming, E. L., and Vitt, F. M.: Influence of extremely large solar proton events in a changing stratosphere, J. Geophys. Res., 105, 11 659-11 670, 2000.

Jackman, C. H., McPeters, R. D., Labow, G. J., Fleming, E. L., Praderass, C. J., and Russell, J. M.: Northern hemisphere atmo- spheric effects due to the July 2000 solar proton event, Geophys. Res. Lett., 28, 2883-2886, 2001.

Jackman, C. H., DeLand, M. T., Labow, G. J., Fleming, E. L., Weisenstein, D. K., Ko, M. K. W., Sinnhuber, M., and Russell, J. M.: Neutral atmospheric influences of the solar proton events in October-November 2003, J. Geophys. Res., 110, A09S27, doi:10.1029/2004JA010888, 2005a.

Jackman, C. H., DeLand, M. T., Labow, G. J., Fleming, E. L., Weisenstein, D. K., Ko, M. K. W., Sinnhuber, M., Anderson, J., and Russell, J. M.: The influence of the several very large solar proton events in Years 2000-2003 on the neutral middle atmosphere, Adv. Space Res., 35, 445-450, 2005b.

Jackman, C. H., Roble, R. G., and Fleming, E. L.: Mesospheric dynamical changes induced by the solar proton events in October-November 2003, Geophys. Res. Lett., 34, L04812, doi:10.1029/2006GL028328, 2007.

Kinnison, D. E., Brasseur, G. P., Walters, S., Garcia, R. R., Marsh, D. R., Sassi, F., Harvey, V. L., Randall, C. E., Emmons, L., Lamarque, J. F., Hess, P., Orlando, J. J., Tie, X. X., Randel, W., Pan, L. L., Gettelman, A., Granier, C., Diehl, T., Niemeier, U., and Simmons, A. J.: Sensitivity of chemical tracers to meteorological parameters in the MOZART-3 chemical transport model, J. Geophys. Res., 112, D20302, doi:10.1029/2006JD007879, 2007.

Krivolutsky, A., Ondraskova, A., and Lastovicka, J.: Photochemical response of neutral and ionized middle atmosphere composition to the strong solar proton event of October 1989, Adv. Space Res., 27, 1975-1981, 2001.

Krivolutsky, A., Kuminov, A., Vyushkova, T., Pereyaslova, N., and Nazarova, M.: Proton activity of the Sun during 23rd solar maximum and its response in ozonosphere of the Earth, Adv. Space Res., 31, 2151-2156, 2003.

Krivolutsky, A., Kuminov, A., and Vyushkova, T.: Ionization of the atmosphere caused by solar protons and its influence on ozonosphere of the Earth during 1994-2003, J. Atmos. Solar-Terr. Phys., 67, 105-117, 2005.

Krivolutsky, A. A., Klyuchnikova, A. V., Zakharov, G. R., Vyushkova, T. Y., and Kuminov, A. A.: Dynamical response of the middle atmosphere to solar proton event of July 2000: Threedimensional model simulations, Adv. Space Res., 37, 16021613, 2006.

López-Puertas, M., Funke, B., Gil-López, S., von Clarmann, T., Stiller, G. P., Höpfner, M., Kellmann, S., Fischer, H., and Jackman, C. H.: Observation of $\mathrm{NO}_{\mathrm{x}}$ enhancement and ozone depletion in the Northern and Southern Hemispheres after the October-November 2003 solar proton events, J. Geophys. Res., 110, A09S43, doi:10.1029/2005JA011050, 2005a.

López-Puertas, M., Funke, B., Gil-López, S., Tsidu, G. M., Fischer, H., and Jackman, C. H.: $\mathrm{HNO}_{3}, \mathrm{~N}_{2} \mathrm{O}_{5}$, and $\mathrm{ClONO}_{2}$ enhancements after the October-November 2003 solar proton events, J. Geophys. Res., 110, A09S44, doi:10.1029/2005JA011051, 2005b.

Marsh, D. R., Garcia, R. R., Kinnison, D. E., Boville, B. A., Sassi, F., Solomon, S. C., and Matthes, K.: Modeling the whole atmosphere response to solar cycle changes in radiative and geomagnetic forcing, J. Geophys. Res., 112, D23306, doi:10.1029/2006JD008306. 2007.

McPeters, R. D.: A nitric oxide increase observed following the July 1982 solar proton event, Geophys. Res. Lett., 13, 667-670, 
1986.

McPeters, R. D. and Jackman, C. H.: The response of ozone to solar proton events during solar cycle 21: the observations, J. Geophys. Res., 90, 7945-7954, 1985.

McPeters, R. D., Jackman, C. H., and Stassinopoulos, E. G.: Observations of ozone depletion associated with solar proton events, J. Geophys. Res., 86, 12 071-12 081, 1981.

Nash, E. R., Newman, P. A., Rosenfield, J. E., and Schoeberl, M. R.: An objective determination of the polar vortex using Ertel's potential vorticity, J. Geophys. Res., 101, 9471-9478, 1996.

Natarajan, M., Remsberg, E. E., Deaver, L. E., and Russell III, J. M.: Anomalously high levels of $\mathrm{NO}_{\mathrm{x}}$ in the polar upper stratosphere during April, 2004: Photochemical consistency of HALOE observations, Geophys. Res. Lett., 31, L15113, doi:10.1029/2004GL020566, 2004.

Orsolini, Y. J., Manney, G. L., Santee, M. L., and Randall, C. E.: An upper stratospheric layer of enhanced $\mathrm{HNO}_{3}$ following exceptional solar storms, Geophys. Res. Lett., 32, L12S01, doi:10.1029/2004GL021588, 2005.

Porter, H. S., Jackman, C. H., and Green, A. E. S.: Efficiencies for production of atomic nitrogen and oxygen by relativistic proton impact in air, J. Chem. Phys., 65, 154-167, 1976.

Randall, C. E., Siskind, D. E., and Bevilacqua, R. M.: Stratospheric $\mathrm{NO}_{\mathrm{x}}$ enhancements in the southern hemisphere polar vortex in winter and spring of 2000, Geophys. Res. Lett., 28, 2385-2388, 2001.

Randall, C. E., Harvey, V. L., Manney, G. L. , Orsolini, Y., Codrescu, M., Sioris, C., Brohede, S., Haley, C. S., Gordley, L. L., Zawodny, J. M., and Russell III, J. M.: Stratospheric effects of energetic particle precipitation in 2003-2004, Geophys. Res. Lett., 32, L05802, doi:10.1029/2004GL02203, 2005.

Randall, C. E., Harvey, V. L., Singleton, C. S., Bernath, P. F., Boone, C. D., and Kozyra, J. U.: Enhanced $\mathrm{NO}_{\mathrm{x}}$ in 2006 Linked to Strong Upper Stratospheric Arctic Vortex, Geophys. Res. Lett., 33, L18811, doi:10.1029/2006GL027160, 2006.

Randall, C. E., Harvey, V. L., Singleton, C. S., Bailey, S. M., Bernath, P. F., Codrescu, M., Nakajima, H., and Russell III, J. M.: Energetic particle precipitation effects on the southern hemisphere stratosphere in 1992-2005, J. Geophys. Res., 112, D08308, doi:10.1029/2006JD007696, 2007.

Reagan, J. B., Meyerott, R. E., Nightingale, R. W., Gunton, R. C., Johnson, R. G., Evans, J. E., Imhof, W. L., Heath, D. F., and Krueger, A. J.: Effects of the August 1972 solar particle events on stratospheric ozone, J. Geophys. Res., 86, 1473-1494, 1981.

Reid, G. C., Solomon, S., and Garcia, R. R.: Response of the middle atmosphere to the solar proton events of August-December 1989, Geophys. Res. Lett., 18, 1019-1022, 1991.

Richter, J. H. and Garcia, R. R.: On the forcing of the Mesospheric Semi-Annual Oscillation in the Whole Atmosphere Community Climate Model, Geophys. Res. Lett., 33, L01806, doi:10.1029/2005GL024378, 2006.

Rinsland, C. P., Boone, C., Nassar, R., Walker, K., Bernath, P., McConnell, J. C., and Chiou, L.: Atmospheric Chemistry Experiment (ACE) Arctic stratospheric measurements of $\mathrm{NO}_{\mathrm{x}}$ during February and March 2004: Impact of intense solar flares, Geophys. Res. Lett., 32, L16S05, doi:10.1029/2005GL022425, 2005.

Roble, R. G., Emery, B. A., Killeen, T. L., Reid, G. C., Solomon, S., Garcia, R. R., Evans, D. S., Carignan, G. R., Heelis, R. A.,
Hanson, W. B., Winningham, D. J., Spencer, N. W., and Brace, L. H.: Joule heating in the mesosphere and thermosphere during the 13 July 1982, solar proton event, J. Geophys. Res., 92, 60836090, 1987.

Rodgers, C. D.: Inverse Methods for Atmospheric Sounding, Theory and Practice, World Scientific, 2000.

Rohen, G., von Savigny, C., Sinnhuber, M., Llewellyn, E. J., Kaiser, J. W., Jackman, C. H., Kallenrode, M.-B., Schröter, J., Eichmann, K.-U., Bovensmann, H., and Burrows, J. P.: Ozone depletion during the solar proton events of Oct./Nov. 2003 as seen by SCIAMACHY, J. Geophys. Res., 110, A09S39, doi:10.1029/2004JA010984, 2005.

Rusch, D. W., Gerard, J.-C., Solomon, S., Crutzen, P. J., and Reid, G. C.: The effect of particle precipitation events on the neutral and ion chemistry of the middle atmosphere, 1, Odd nitrogen, Planet. Space Sci., 29, 767-774, 1981.

Sander, S. P., Friedl, R. R., Golden, D. M., Kurylo, M. J., Huie, R. E., Orkin, V. L., Moortgat, G. K., Ravishankara, A. R., Kolb, C. E., Molina, M. J., and Finlayson-Pitts, B. J.: Chemical kinetics and photochemical data for use in atmospheric studies, Evaluation 14, JPL Publ. 02-25, 2003.

Sassi, F., Garcia, R. R., Boville, B. A., and Liu, H.: On temperature inversions and the mesospheric surf zone, J. Geophys. Res., 107, 4380, doi:10.1029/2001JD001525, 2002.

Sassi, F., Kinnison, D., Boville, B. A., Garcia, R. R., and Roble, R.: Effect of El Nino-Southern Oscillation on the dynamical, thermal, and chemical structure of the middle atmosphere, J. Geophys. Res., 109, D17108, doi:10.1029/2003JD004434, 2004.

Semeniuk, K., McConnell, J. C., and Jackman, C. H.: Simulation of the October-November 2003 solar proton events in the CMAM GCM: Comparison with observations, Geophys. Res. Lett. 32, L15S02, doi:10.1029/2004GL022392, 2005.

Seppälä, A., Verronen, P. T., Kyrölä, E., Hassinen, S., Backman, L., Hauchecorne, A., Bertaux, J. L., and Fussen, D.: Solar proton events of October-November 2003: Ozone depletion in the Northern Hemisphere polar winter as seen by GOMOS/Envisat, Geophys. Res. Lett., 31, L19107, doi:10.1029/2004GL021042, 2004.

Seppälä, A., Verronen, P. T., Sofieva, V. F., Tamminen, J., Kyrölä, E., Rodger, C. J., and Clilverd, M. A.: Destruction of the tertiary ozone maximum during a solar proton event, Geophys. Res. Lett., 33, L07804, doi:10.1029/2005GL025571, 2006.

Solomon, S. and Crutzen, P. J.: Analysis of the August 1972 solar proton event including chlorine chemistry, J. Geophys. Res., 86, 1140-1146, 1981.

Solomon, S., Rusch, D. W., Gerard, J.-C., Reid, G. C., and Crutzen, P. J.: The effect of particle precipitation events on the neutral and ion chemistry of the middle atmosphere, 2, Odd hydrogen, Planet. Space Sci., 29, 885-892, 1981.

Solomon, S., Reid, G. C., Rusch, D. W., and Thomas, R. J.: Mesospheric ozone depletion during the solar proton event of 13 July 1982, 2, Comparison between theory and measurements, Geophys. Res. Lett., 10, 257-260, 1983.

Swider, W. and Keneshea, T. J.: Decrease of ozone and atomic oxygen in the lower mesosphere during a PCA event, Planet. Space Sci., 21, 1969-1973, 1973.

Swider, W., Keneshea T. J., and Foley, C. I.: An SPE disturbed Dregion model, Planet. Space Sci., 26, 883-892, 1978.

Thomas, R. J., Barth, C. A., Rottman, G. J., Rusch, D. W., Mount, 
G. H., Lawrence, G. M., Sanders, R. W., Thomas, G. E., and Clemens, L. E.: Mesospheric ozone depletion during the solar proton event of 13 July 1982, 1, Measurements, Geophys. Res. Lett., 10, 257-260, 1983.

Verronen, P. T., Turunen, E., Ulich, T., and Kyrola, E.: Modeling the effects of the October 1989 solar proton event on mesospheric odd nitrogen using a detailed ion and neutral chemistry model, Ann. Geophys., 20, 1967-1976, 2002, http://www.ann-geophys.net/20/1967/2002/.

Verronen, P. T., Seppala, A., Clilverd, M. A., Rodger, C. J., Kyrola, E., Enell, C.-F., Ulich, T., and Turunen, E.: Diurnal variation of ozone depletion during the October-November 2003 solar proton events, J. Geophys. Res., 110, A09S32, doi:10.1029/2004JA010932, 2005.

Verronen, P. T., Seppala, A., Kyrola, E., Tamminen, J., Pickett, H. M., and Turunen, E.: Production of odd hydrogen in the mesosphere during the January 2005 solar proton event, Geophys. Res. Lett., 33, L24811, doi:10.1029/2006GL028115, 2006.

von Clarmann, T., Glatthor, N., Grabowski, U., Höpfner, M., Kellmann, S., Kiefer, M., Linden, A., Mengistu Tsidu, G., Milz, M., Steck, T., Stiller, G. P., Wang, D. Y., Fischer, H., Funke, B., GilLópez, S., and López-Puertas, M.: Retrieval of temperature and tangent altitude pointing from limb emission spectra recorded from space by the Michelson Interferometer for Passive Atmospheric Sounding (MIPAS), J. Geophys. Res., 108(D23), 4736, doi:10.1029/2003JD003602, 2003. von Clarmann, T., Glatthor, N., Höpfner, M., Kellmann, S., Ruhnke, R., Stiller, G. P., and Fischer, H.: Experimental evidence of perturbed odd hydrogen and chlorine chemistry after the October 2003 solar proton events, J. Geophys. Res., 110, A09S45, doi:10.1029/2005JA011053, 2005.

Vitt, F. M. and Jackman, C. H.: A comparison of sources of odd nitrogen production from 1974 through 1993 in the Earth's middle atmosphere as calculated using a two-dimensional model, J. Geophys. Res., 101, 6729-6739, 1996.

Vitt, F. M., Armstrong, T. P., Cravens, T. E., Dreschhoff, G. A. M., Jackman, C. H., and Laird, C. M.: Computed contributions to odd nitrogen concentrations in the Earth's polar middle atmosphere by energetic charged particles, J. Atmos. Solar-Terr. Phys., 62, 669-683, 2000.

Warneck, P.: Cosmic radiation as a source of odd nitrogen in the stratosphere, J. Geophys. Res., 77, 6589-6591, 1972.

Weeks, L. H., CuiKay, R. S., and Corbin, J. R.: Ozone measurements in the mesosphere during the solar proton event of 2 November 1969, J. Atmos. Sci., 29, 1138-1142, 1972.

Zadorozhny, A. M., Tuchkov, G. A., Kikhtenko, V. N., Lastovicka, J., Boska, J., and Novak, A.: Nitric oxide and lower ionosphere quantities during solar particle events of October 1989 after rocket and ground-based measurements, J. Atmos. Terr. Phys., 54, 183-192, 1992. 